\title{
23. SEISMIC VELOCITY-POROSITY RELATIONSHIP OF SULFIDE, SULFATE, AND BASALT SAMPLES FROM THE TAG HYDROTHERMAL MOUND ${ }^{1}$
}

\author{
Rainer J. Ludwig, ${ }^{2}$ Gerardo J. Iturrino, ${ }^{3}$ and Peter A. Rona ${ }^{4}$
}

\begin{abstract}
Physical properties and ultrasonic velocity measurements on 24 minicores recovered at the Trans-Atlantic Geotraverse (TAG) hydrothermal mound during Ocean Drilling Program Leg 158 provide a unique reference data set for subsurface sulfide, sulfate, and basalt samples from an active sediment-free hydrothermal system. Seismic velocities, densities, porosities, and the distribution of pore shapes are extremely variable both horizontally and vertically within the mound. However, if the sulfide and sulfate samples are classified according to their mineralogy and their location within major internal lithologic zones of the mound, the measured physical properties exhibit distinct characteristics.

Ultrasonic seismic velocities of the samples were determined at confining pressures of 5 to $100 \mathrm{MPa}$. Compressional-wave $\left(V_{p}\right)$ and two orthogonal shear-wave $\left(V_{s}\right)$ velocities were measured with a single transducer. The transducer geometry allowed for testing of anisotropy effects, observed only for massive sulfide samples recovered in close proximity to the active Black Smoker Complex. $V_{p} / V_{s}$ ratios for rock types of the different internal zones are distinctive: high values of 1.9 for massive sulfides near the seafloor, medium values averaging 1.7 for anhydrite-rich samples, and low values of 1.55 for the deeper, more silicified samples. Seismic velocities of basalt samples, which were recovered at the edges of the mineralized upflow zone, are relatively low $\left(V_{p}=6.1 \mathrm{~km} / \mathrm{s} ; V_{s}=3.4 \mathrm{~km} / \mathrm{s}\right)$ compared with "normal" mid-ocean ridge basalts. The relatively low basalt porosity $(\sim 1.5 \%)$ tends to indicate that low velocities are caused by hydrothermal alteration rather than porosity effects.

We present for the first time results of an iterative model using rock physics theories that relate seismic velocities to porosity structure on a hand-sample scale and estimate the distribution of pore-aspect ratios for minicore samples, which are representative of each major lithologic zone within the TAG mound. Microscopic observations on thin sections and index properties provided effective constraints as initial models. Computed porosity models yield satisfactory results that match both the visual observations of pore shapes and the seismic velocity measurements. This analysis will provide useful constraints on future studies exploring permeability, fluid flow, and alteration mechanisms of hydrothermal systems.
\end{abstract}

\section{INTRODUCTION}

Ocean Drilling Program (ODP) Leg 158 provided a unique opportunity for subsurface sampling of a hydrothermal system by drilling a series of holes into a large, sediment-free active mound in the Trans-Atlantic Geotraverse (TAG) hydrothermal field on the eastern side of the median valley of the Mid-Atlantic Ridge. The active hightemperature field lies on oceanic crust that is at least 100,000 years old, as calculated from half-spreading rates of $13 \mathrm{~mm} / \mathrm{yr}$ to the east and $11 \mathrm{~mm} / \mathrm{yr}$ to the west (McGregor et al., 1977). Although hydrothermal deposits have been found over an area of about $5 \times 5 \mathrm{~km}^{2}$ about $1.5 \mathrm{~km}$ to the east of the bathymetric axis of the rift valley, known high-temperature venting is presently confined to the TAG active mound. The mound is located at a water depth of $3650 \mathrm{~m}$ at $26^{\circ} 08^{\prime} \mathrm{N}$ and $44^{\circ} 49^{\prime} \mathrm{W}$ (Fig. 1) and is strikingly circular in shape, with a diameter of about $200 \mathrm{~m}$ and a height of $50 \mathrm{~m}$, compared to the surrounding seafloor (Rona et al., 1993; 1986).

This paper will concentrate on the subsurface physical structure of the predominantly sulfide-rich rocks drilled at the TAG hydrothermal system, as well as the underlying basement rocks recovered in the deeper sections of Site 957 boreholes. Mineralization of ocean crust occurs where metals, leached from large volumes of altered crust at depth, are concentrated at or near the surface by hydrothermal circu-

${ }^{1}$ Herzig, P.M., Humphris, S.E., Miller, D.J., and Zierenberg, R.A. (Eds.), 1998. Proc. ODP, Sci. Results, 158: College Station, TX (Ocean Drilling Program).

${ }^{2}$ School of Ocean and Earth Science and Technology, University of Hawaii at Manoa, Honolulu, HI 96822, U.S.A. (Present address: Oxford Instruments, Scientific Research Division, Concord, MA 01742, U.S.A.) ludwig@oxford.usa.com.

${ }^{3}$ Lamont-Doherty Earth Observatory, Columbia University, Palisades, NY 10964, U.S.A.

${ }^{4}$ Institute of Marine and Coastal Sciences, Rutgers University, New Brunswick, NJ 08903, U.S.A. lation (Hannington et al., 1995). Hydrothermal alteration and the formation of secondary minerals influences the seismic velocity, density, and porosity structure of oceanic crust (Wilkens et al., 1991). Post-cruise ultrasonic measurements on minicore samples determined both compressional- and shear-wave velocities. Their relationship to other physical properties, especially the porosity and poreshape distribution of the samples, are reported here.

\section{EXPERIMENTAL TECHNIQUES AND ANALYTICAL METHODS \\ Sample Preparation}

Twenty horizontally oriented and four unoriented minicores with diameters of $2.54 \mathrm{~cm}$ were drilled perpendicular to the in situ vertical axis of the core. The minicores were carefully polished with 240 and/ or 600 grit on a glass plate to ensure parallel faces within $0.02 \mathrm{~mm}$ and to smooth the contact area. In order to saturate the samples and displace air from their pores, the minicores were immersed in seawater and put under a vacuum in a bell jar for 24 to $48 \mathrm{hr}$ before velocity measurements were made. Polished thin sections were made from 10 sample stubs for petrographic analyses and microscopic analysis of the porosity structure.

\section{Determination of Index Properties}

Index properties (bulk density, grain density, bulk water content, porosity) were calculated from measurements of wet and dry sample weights and dry volumes for all minicores. For the wet measurements, samples were saturated in seawater and placed in a vacuum for $24 \mathrm{hr}$ to approximate in situ wet conditions. After the wet measurements were made, the sulfide and basalt samples were dried for $24 \mathrm{hr}$ at $35^{\circ} \mathrm{C}$ and $60^{\circ} \mathrm{C}$, respectively. The relatively low drying tempera-

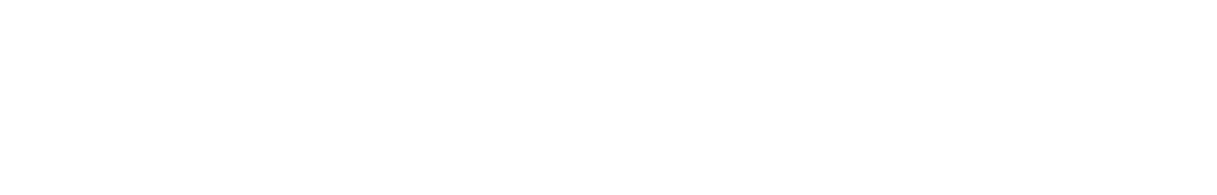




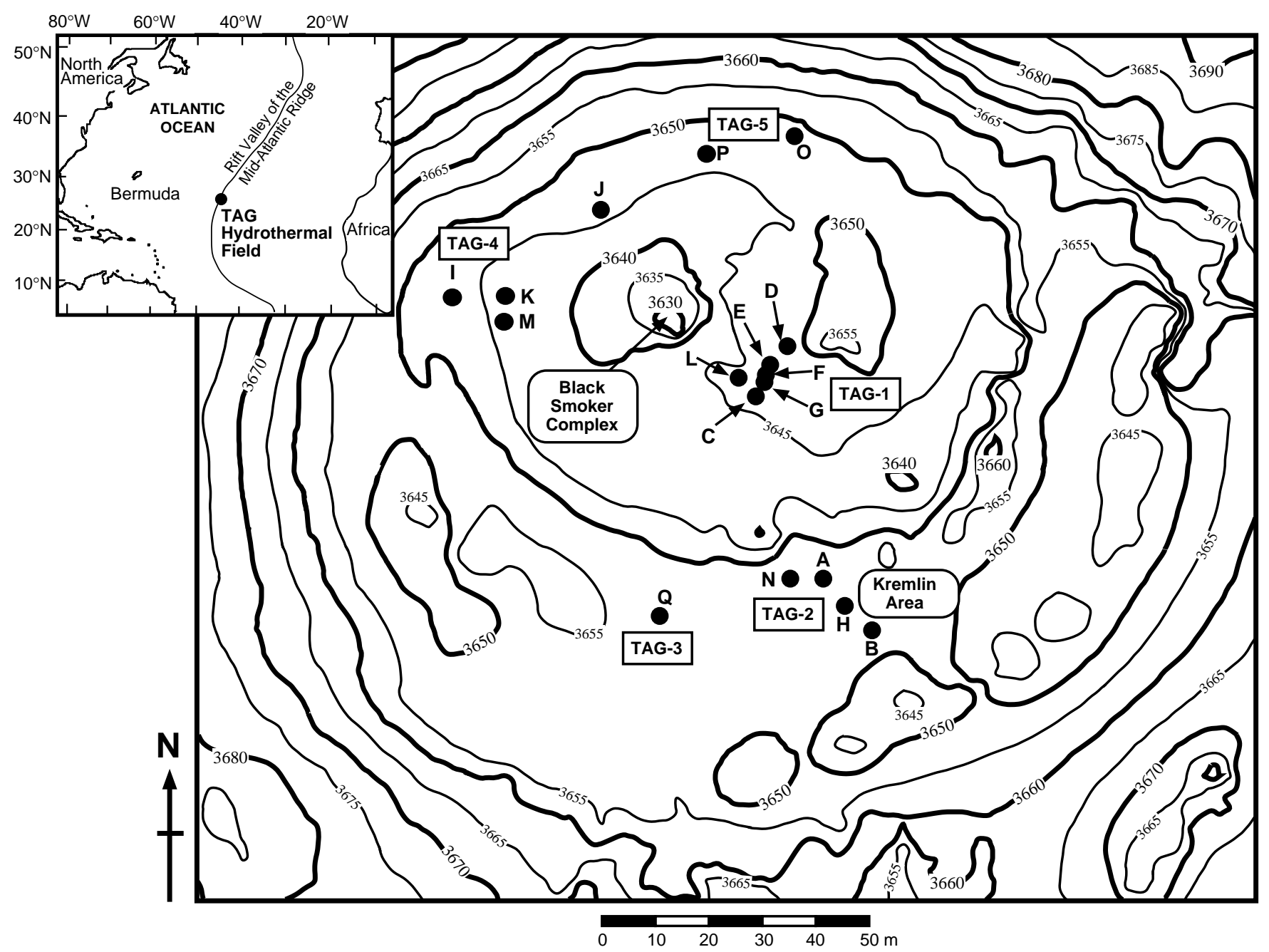

Figure 1. High-resolution bathymetric map (5-m contour interval) of the active TAG hydrothermal mound, showing its overall morphology and the major areas of venting: the Black Smoker Complex and the Kremlin Area (from Humphris et al., 1995). The relative locations of the 17 holes (A through Q) drilled during Leg 158 and the subdivision of the active mound into five areas (TAG-1 through TAG-5) are indicated. The inset shows the location of the TAG hydrothermal field along the Mid-Atlantic Ridge.

ture for the sulfides was necessary to reduce possible oxidation. Experiments with different drying times confirmed that even at $35^{\circ} \mathrm{C}$, one day was sufficient to completely dry the samples because of their relatively high porosity. All measurements were corrected for salt content assuming a pore fluid salinity of $3.5 \%$.

Aboard the JOIDES Resolution, sample mass was determined to a precision of $\pm 0.01 \mathrm{~g}$ using a Scitech electronic balance with a computer averaging system to compensate for ship motion. Volumes were determined using a Quantachrome Penta-Pycnometer. The calculation of index properties derived from these measurements is explained in detail in the "Physical Properties" section of the "Explanatory Notes" chapter of Humphris, Herzig, Miller, et al. (1996). Index properties for the 24 minicores used for shore-based ultrasonic measurements are presented in Table 1.

\section{Porosity Constraints}

During minicore preparation, polished thin sections were made from 10 core-end billets for petrographic analysis and microscopic examination of the porosity structure. These analyses were used to refine visual observations of the porosity structure for the different rock types and to document textural relationships and mineralogy in greater detail. A summary of the results is presented in Table 2, along with the total porosity $(\Phi)$ determined from the index properties measurements. This study provided necessary constraints and starting models discussed later in the "Porosity Models" section (this chapter).

\section{Ultrasonic Measurements}

Seismic velocities were measured at the Petrophysics Laboratory of the University of Miami Rosenstiel School of Marine and Atmospheric Science (RSMAS). Velocities were measured using a 100 $\mathrm{MPa}(1 \mathrm{kbar})$ velocimeter at hydrostatic pressures ranging from 5 to $100 \mathrm{MPa}$ and a constant pore pressure of $2 \mathrm{MPa}$. The same instrument was used by Gröschel-Becker et al. (1994) to measure ultrasonic velocities on eight sediment-hosted sulfide minicores recovered from Holes $856 \mathrm{G}$ and $856 \mathrm{H}$ that were drilled at Middle Valley on the Northern Juan de Fuca Ridge during Leg 139. A unique feature of the system's $1 \mathrm{MHz}$ transducer configuration is that two orthogonal shear waves ( $S 1$ and $S 2$ ) are propagated through the sample along with a single compressional wave. The minicores were aligned so that the $S 2$ wave propagated in the plane defined by the orientation marks of the sample, whereas the $S 1$ wave propagated in a plane oriented $90^{\circ}$ from the $S 2$ plane (Fig. 2). The precision of both $V_{p}$ and $V_{s}$ measurements is $\sim 1 \%-2 \%$.

The ultrasonic data of this study are presented in Table 3. 
Table 1. Index properties of the 24 ultrasonically measured minicores collected during Leg 158 at the TAG hydrothermal mound.

\begin{tabular}{|c|c|c|c|c|c|}
\hline $\begin{array}{l}\text { Core, section, } \\
\text { interval }(\mathrm{cm})\end{array}$ & $\begin{array}{l}\text { Depth } \\
\text { (mbsf) }\end{array}$ & $\begin{array}{l}\text { Bulk density } \\
\left(\mathrm{g} / \mathrm{cm}^{3}\right)\end{array}$ & $\begin{array}{l}\text { Grain density } \\
\left(\mathrm{g} / \mathrm{cm}^{3}\right)\end{array}$ & $\begin{array}{c}\text { Total porosity } \\
(\%)\end{array}$ & Rock type \\
\hline \multicolumn{6}{|c|}{ TAG- 1 (East of Black Smoker Complex) } \\
\hline $7 \mathrm{~N}-2,8-10$ & 20.93 & 3.35 & 3.62 & 10.49 & Nodular silicified pyrite-anhydrite breccia \\
\hline $7 \mathrm{~N}-2,114-116$ & 21.99 & 3.40 & 3.82 & 15.22 & Anhydrite vein \\
\hline $7 \mathrm{~N}-3,15-17$ & 22.50 & 2.79 & 2.98 & 9.62 & Anhydrite vein \\
\hline $11 \mathrm{~N}-3,118-120$ & 34.79 & 3.42 & 3.52 & 3.90 & Pyrite-silica breccia \\
\hline $15 \mathrm{~N}-1,115-117$ & 43.35 & 3.58 & 3.67 & 3.59 & Silicified wallrock breccia \\
\hline $16 \mathrm{~N}-1,35-37$ & 46.55 & 3.21 & 3.33 & 5.12 & Nodular pyrite-silica breccia \\
\hline \multicolumn{6}{|l|}{$158-957 \mathrm{E}-$} \\
\hline $158-957 \mathrm{E}-$ & & 5.00 & 3.40 & 0.40 & 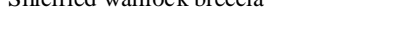 \\
\hline $15 \mathrm{R}-1,30-32$ & 106.80 & 3.49 & 3.62 & 4.89 & Chloritized basalt \\
\hline $1 \mathrm{~N}-1,62-64$ & 1.62 & 3.57 & 3.83 & 9.28 & Massive pyrite breccia \\
\hline $1 \mathrm{~N}-1,71-73$ & 1.71 & 3.68 & 3.80 & 4.48 & Massive pyrite breccia \\
\hline \multicolumn{6}{|l|}{ 158-957G- } \\
\hline $3 \mathrm{~N}-1,12-14$ & 21.12 & 4.10 & 4.40 & 9.14 & Massive pyrite-anhydrite breccia \\
\hline \multicolumn{6}{|l|}{ TAG-2 (Kremlin Area) } \\
\hline $5 N-1,4-6$ & 26.74 & 4.62 & 4.96 & 8.58 & Massive granular pyrite \\
\hline $5 \mathrm{~N}-2,29-31$ & 27.89 & 4.33 & 4.69 & 9.92 & Silicified wallrock breccia \\
\hline \multicolumn{6}{|l|}{$158-957 \mathrm{~N}-$} \\
\hline 1W-1, 62-64 & 0.62 & 3.45 & 3.64 & 7.36 & Nodular pyrite-silica breccia \\
\hline \multicolumn{6}{|c|}{ TAG-4 (West of Black Smoker Complex) } \\
\hline \multicolumn{6}{|l|}{$158-957 \mathrm{M}-$} \\
\hline $9 \mathrm{R}-1,61-63$ & 42.91 & 2.88 & 2.90 & 1.17 & Altered basalt \\
\hline 10R-1, 39-41 & 46.59 & 2.88 & 2.91 & 1.45 & Altered basalt \\
\hline $10 \mathrm{R}-1,47-49$ & 46.67 & 2.87 & 2.90 & 1.70 & Altered basalt \\
\hline \multicolumn{6}{|c|}{ TAG-5 (North of Black Smoker Complex) } \\
\hline $\begin{array}{l}158-957 \mathrm{O}- \\
2 \mathrm{R}-1.34-36\end{array}$ & & & & & \\
\hline 2R-1, 34-36 & 8.24 & 3.94 & 4.27 & 10.22 & Nodular pyrite breccia \\
\hline $4 \mathrm{R}-1,19-21$ & 16.09 & 3.71 & 3.93 & 7.69 & Pyrite-anhydrite breccia \\
\hline $4 \mathrm{R}-1,29-31$ & 16.19 & 4.19 & 4.46 & 7.84 & Nodular pyrite-anhydrite breccia \\
\hline \multicolumn{6}{|l|}{ 158-957P- } \\
\hline $1 \mathrm{R}-1,49-51$ & 0.49 & 3.56 & 4.04 & 15.95 & Pyrite-anhydrite breccia \\
\hline $6 \mathrm{R}-1,11-13$ & 26.61 & 4.23 & 4.56 & 9.29 & Nodular pyrite breccia \\
\hline $9 \mathrm{R}-1,4-6$ & 40.14 & 3.27 & 3.39 & 4.95 & Nodular pyrite-silica breccia \\
\hline $12 \mathrm{R}-2,67-69$ & 56.31 & 4.31 & 4.43 & 3.42 & Pyrite-silica breccia \\
\hline
\end{tabular}

The seismic velocities were measured during increasing pressure cycles at 5-MPa increments between 5 and $20 \mathrm{MPa}$ and at 10-MPa increments between 20 and $100 \mathrm{MPa}$. An exception was made for measurements on an almost pure anhydrite sample (Sample 158-957C$7 \mathrm{~N}-3,15-17 \mathrm{~cm}$, denoted with an asterisk [*] in Table 3). The delicate nature of the anhydrite in a water-saturated state required rapid measurements, which were made in 10-MPa increments starting at a confining pressure of $20 \mathrm{MPa}$ and increasing to $100 \mathrm{MPa}$. Thereafter, the pressure was slowly reduced, and the remaining ultrasonic measurements were performed at 15,10 , and $5 \mathrm{MPa}$, respectively.

\section{SAMPLE DESCRIPTIONS}

One of the most striking features of the TAG mound is the dominance of breccias throughout the mound and in the upper parts of the underlying zone of hydrothermal fluid upflow. Four major zones were identified based on the overall internal structure of the mound and the upflow zone. (Humphris et al., 1995).

Samples are described according to the sulfide classification scheme developed aboard the ship (Humphris, Herzig, Miller, et al., 1996), unless the minicore mineralogy is distinctively different from the surrounding structure described in the shipboard sulfide log (Humphris, Herzig, Miller, et al., 1996).

Zone 1 consists of massive sulfides reflecting the formation of new hydrothermal precipitates (Tables 1-3; Fig. 3). This zone is restricted to the upper few meters at each drilling location.

Zone 1 is underlain by an anhydrite-rich Zone 2, identified only in the TAG-1 and TAG-5 areas (Tables 1-3; Fig. 3). Anhydrite veining is extremely well developed throughout this zone, and composite veins up to $45 \mathrm{~cm}$ thick are present. The minicore samples from this zone are very porous, and many void spaces of different shapes can be identified visually and microscopically (Table 2). Most of the cracks and vesicular pores are concentrated near the anhydrite veins. These are composed of complex, multistage fracture fillings and cavity linings, and some include disseminated, fine-grained pyrite and chalcopyrite.

Zone 3 is intensely silicified and consists of dominantly clastsupported and brecciated wallrock that forms the upflow zone beneath the mound. The wallrock occurs below pyrite-silica breccias and is distinguished from the overlying breccias by less pyrite $(<50 \%$ by volume). Seven of the 24 minicore samples analyzed in this study represent Zone 3 (Tables 1-3; Fig. 3).

Zone 4 starts about $100 \mathrm{~m}$ below seafloor (mbsf), where the silicified wallrock breccias grade into a chloritized basalt breccia (Tables 1-3; Fig. 3). In this zone, chloritized and weakly mineralized basalt fragments $(1-5 \mathrm{~cm}$ in size) are cemented by quartz and pyrite and are crosscut by veins of pyrite, quartz, and quartz plus pyrite.

Relatively unaltered pillow basalts were recovered near the edges of the mound at depths of about 25 mbsf at TAG-2 and 45 mbsf at TAG-4 (Tables 1-3). These basalts constrain the lateral extent of intense crustal alteration and mineralized upflow zone to about $80 \mathrm{~m}$.

\section{GENERAL RESULTS}

Compressional-wave velocities $\left(V_{p}\right)$ at a confining pressure of 100 MPa for all 24 minicore samples vs. depth are shown in Figure 3. The major lithologic zones of the TAG mound can easily be identified. Although very porous (about $10 \%$; Table 1), the massive sulfides of Zone 1 all have relatively high seismic velocities of 5.3 to $5.8 \mathrm{~km} / \mathrm{s}$ because of their high pyrite content. A large variation in $\mathrm{V}_{p}$ is observed in samples from about $22 \mathrm{mbsf}$ in the underlying anhydriterich Zone 2. The almost pure anhydrite Sample 957C-7N-3, 15-17 


\begin{tabular}{|c|c|c|c|c|c|c|c|c|c|c|}
\hline \multirow[b]{2}{*}{$\begin{array}{l}\text { Core, section, } \\
\text { interval }(\mathrm{cm})\end{array}$} & \multirow[b]{2}{*}{$\begin{array}{l}\text { Depth } \\
\text { (mbsf) }\end{array}$} & \multirow[b]{2}{*}{ Rock type } & \multirow[b]{2}{*}{ Observed porosity structure } & \multicolumn{5}{|c|}{ Major sulfide mineralogy $(\%)$} & \multirow[b]{2}{*}{ Comments } & \multirow{2}{*}{$\begin{array}{c}\text { Total } \\
\text { porosity } \\
(\%)\end{array}$} \\
\hline & & & & Pyrite & Chalcopyrite & Anhydrite & Quartz & Clays & & \\
\hline \multicolumn{11}{|c|}{ TAG-1 (East of Black Smoker Complex) } \\
\hline $\begin{array}{r}158-957 \mathrm{C}- \\
7 \mathrm{~N}-2,8-10\end{array}$ & 20.93 & Nodular silicified pyrite-anhydrite breccia & $\begin{array}{l}\text { Thin section: high porosity, many thin cracks, some } \\
\text { vesicular }\end{array}$ & 40 & 10 & 40 & 10 & & Cracks adjacent to massive pyrite clasts & 10.49 \\
\hline $7 \mathrm{~N}-2,114-116$ & 21.99 & Anhydrite vein & $\begin{array}{l}\text { Visual: high porosity, large spherical pore spaces, } \\
\text { thin cracks and veins }\end{array}$ & & & 75 & 25 & & $\begin{array}{l}\text { Large anhydrite clasts, chimney } \\
\text { fragments }\end{array}$ & 15.22 \\
\hline $7 \mathrm{~N}-3,15-17$ & 22.50 & Anhydrite vein & $\begin{array}{l}\text { Thin section: high porosity, large fluid inclusions, } \\
\text { large vapor bubbles }\end{array}$ & 1 & 4 & 95 & & & Pure anhydrite with cavity filling & 9.62 \\
\hline $11 \mathrm{~N}-3,118-120$ & 34.79 & Pyrite-silica breccia & Visual: low porosity, few cracks & 15 & & 5 & 60 & & Highly silicified & 3.90 \\
\hline $15 \mathrm{~N}-1,115-117$ & 43.35 & Silicified wallrock breccia & $\begin{array}{l}\text { Thin section: low porosity, irregular void spaces in } \\
\text { the order of } 100 \mu \mathrm{m} \text {, veins }\end{array}$ & 40 & & & 50 & 10 & Many pyrite clasts are fractured & 3.59 \\
\hline $16 \mathrm{~N}-1,35-37$ & 46.55 & Nodular pyrite-silica breccia & $\begin{array}{l}\text { Thin section: intermediate porosity, mainly cracks } \\
\text { and cavities }\end{array}$ & 25 & & & 65 & & $\begin{array}{l}\text { Pyrite nodules are surrounded by } \\
\text { cavities and cracks }\end{array}$ & 5.12 \\
\hline $\begin{array}{l}158-957 \mathrm{E}- \\
8 \mathrm{R}-1,10-12\end{array}$ & 72.90 & Silicified wallrock breccia & Visual: low porosity, mostly vesicular & 30 & & & 70 & & Angular altered basalt in pyrite-silica & 6.48 \\
\hline $15 \mathrm{R}-1,30-32$ & 106.80 & Chloritized basalt breccia & Visual: low porosity, some thin cracks & 40 & & & 55 & 3 & $\begin{array}{l}\text { Sulfides and quartz occur mainly in } \\
\text { veins }\end{array}$ & 4.89 \\
\hline \multicolumn{11}{|l|}{$158-957 \mathrm{~F}-$} \\
\hline $\begin{array}{l}1 \mathrm{~N}-1,62-64 \\
1 \mathrm{~N}-1,71-73\end{array}$ & $\begin{array}{l}1.62 \\
1.71\end{array}$ & $\begin{array}{l}\text { Massive pyrite breccia } \\
\text { Massive pyrite breccia }\end{array}$ & $\begin{array}{l}\text { Thin section: high porosity } \\
\text { Visual: intermediate porosity }\end{array}$ & $\begin{array}{l}85 \\
85\end{array}$ & $\begin{array}{l}5 \\
5\end{array}$ & $\begin{array}{l}10 \\
10\end{array}$ & & & $\begin{array}{l}\text { Damaged thin section, big pyrite clasts } \\
\text { Big pyrite clasts, small chalcopyrite } \\
\text { clasts }\end{array}$ & $\begin{array}{l}9.28 \\
4.48\end{array}$ \\
\hline $\begin{array}{l}158-957 \mathrm{G}- \\
3 \mathrm{~N}-1,12-14\end{array}$ & 21.12 & Massive pyrite-anhydrite breccia & Visual: low porosity, mostly vesicular & 80 & & 15 & & & $\begin{array}{l}\text { Clasts of pyrite-silica in granular pyrite } \\
\text { matrix }\end{array}$ & 9.14 \\
\hline \multicolumn{11}{|c|}{$\begin{array}{l}\text { TAG-2 (Kremlin Area) } \\
158-957 \mathrm{H}-\end{array}$} \\
\hline $\begin{array}{r}158-957 \mathrm{H}- \\
5 \mathrm{~N}-1,4-6\end{array}$ & 26.74 & Massive granular pyrite & $\begin{array}{l}\text { Visual: low porosity, mostly vesicular adjacent to } \\
\text { nodular pyrite clasts }\end{array}$ & 95 & & & & & Big clasts of nodular pyrite & 8.58 \\
\hline $5 \mathrm{~N}-2,29-31$ & 27.89 & Silicified wallrock breccia & $\begin{array}{l}\text { Thin section: intermediate porosity, some thin } \\
\text { cracks, near quartz veins }\end{array}$ & 60 & & 2 & 30 & 5 & Most open spaces fill with quartz & 9.92 \\
\hline $\begin{array}{l}158-957 \mathrm{~N}- \\
1 \mathrm{~W}-1,62-64\end{array}$ & 0.62 & Nodular pyrite-silica breccia & Visual: low porosity & 30 & & 2 & 65 & & Many quartz veins & 7.36 \\
\hline \multicolumn{11}{|c|}{$\begin{array}{l}\text { TAG-4 (West of Black Smoker Complex) } \\
158-957 \mathrm{M}-\end{array}$} \\
\hline $9 \mathrm{R}-1,61-63$ & 42.91 & Altered basalt & $\begin{array}{l}\text { Thin section: very low porosity }(\approx 1 \%) \text {, mostly } \\
\text { vesicles and other circular voids (size } \approx 0.09-0.3 \\
\text { mm) }\end{array}$ & & & & & & Few cracks and veins & 1.17 \\
\hline $10 \mathrm{R}-1,39-41$ & 46.59 & Altered basalt & $\begin{array}{l}\text { Thin section: very low porosity }(\approx 1-2 \%) \text {, mostly } \\
\text { vesicles and other circular voids (size } \approx 0.1 \mathrm{~mm} \text { ), } \\
\text { some elongated voids }(\approx 0.4 \mathrm{~mm})\end{array}$ & & & & & & $\begin{array}{l}\text { Veins, some hair thin cracks (size }<0.01 \\
\text { mm) }\end{array}$ & 1.45 \\
\hline 10R-1, 47-49 & 46.67 & Altered basalt & Visual: same as other two basalt samples & & & & & & Same as other 2 basalt samples & 1.70 \\
\hline \multicolumn{11}{|c|}{ TAG-5 (North of Black Smoker Complex) } \\
\hline $\begin{array}{l}158-957 \mathrm{O}- \\
2 \mathrm{R}-1,34-36\end{array}$ & 8.24 & Nodular pyrite breccia & $\begin{array}{l}\text { Thin section: high porosity, many cracks adjacent to } \\
\text { anhydrite veins }\end{array}$ & 50 & 10 & 30 & 10 & & $\begin{array}{l}\text { Very porous, anhydrite only partially } \\
\text { fills open spaces }\end{array}$ & 10.22 \\
\hline $\begin{array}{l}4 \mathrm{R}-1,19-21 \\
4 \mathrm{R}-1,29-31\end{array}$ & $\begin{array}{l}16.09 \\
16.19\end{array}$ & $\begin{array}{l}\text { Pyrite-anhydrite breccia } \\
\text { Nodular pyrite-anhydrite breccia }\end{array}$ & $\begin{array}{l}\text { Visual: low porosity } \\
\text { Visual: low porosity }\end{array}$ & $\begin{array}{l}60 \\
75\end{array}$ & $\begin{array}{l}5 \\
3\end{array}$ & $\begin{array}{l}35 \\
20\end{array}$ & & & $\begin{array}{l}\text { Some cracks within anhydrite veins } \\
\text { Big pyrite clasts cut by anhydrite veins }\end{array}$ & $\begin{array}{l}7.69 \\
7.84\end{array}$ \\
\hline $\begin{array}{l}158-957 \mathrm{P}- \\
1 \mathrm{R}-1,49-51\end{array}$ & 0.49 & Pyrite-anhydrite breccia & $\begin{array}{l}\text { Thin section: high porosity, elongated cracks, } \\
\text { unfilled voids near anhydrite veins }\end{array}$ & 60 & 10 & 30 & & & Void spaces concentrated near veins & 15.95 \\
\hline $6 \mathrm{R}-1,11-13$ & 26.61 & Nodular pyrite breccia & $\begin{array}{l}\text { Visual: intermediate porosity, mostly vesicular } \\
\text { adjacent to pyrite clasts }\end{array}$ & 90 & & 9 & & & Massive granular pyrite & 9.29 \\
\hline $9 \mathrm{R}-1,4-6$ & 40.14 & Nodular pyrite-silica breccia & $\begin{array}{l}\text { Visual: low porosity, few circular voids, some thin } \\
\text { cracks }\end{array}$ & 30 & & & 70 & & Nodular pyrite clasts in silica matrix & 4.95 \\
\hline $12 \mathrm{R}-2,67-69$ & 56.31 & Pyrite-silica breccia & $\begin{array}{l}\text { Visual: low porosity, few circular voids, very few } \\
\text { thin cracks }\end{array}$ & 35 & & & 60 & 5 & $\begin{array}{l}\text { Wallrock clasts extensively replaced by } \\
\text { silica and pyrite }\end{array}$ & 3.42 \\
\hline
\end{tabular}


$\mathrm{cm}$, has $V_{p}=4.42 \mathrm{~km} / \mathrm{s}$, and a massive pyrite-anhydrite breccia (Sample $957 \mathrm{G}-3 \mathrm{~N}-1,12-14 \mathrm{~cm}$ ) has $V_{p}=6.26 \mathrm{~km} / \mathrm{s}$. Zone 3 extends from about 25 to $100 \mathrm{mbsf}$, and most samples have $V_{p}$ of about $5.7 \mathrm{~km} / \mathrm{s}$. However, two pyrite-rich samples have an considerably high $V_{p}$ of about $6.8 \mathrm{~km} / \mathrm{s}$ (Samples 957H-5N-2, 29-31 cm, and 957P-12R-2, $67-69 \mathrm{~cm})$. The one sample from Zone 4 , a chloritized basalt breccia (Sample 957E-15R-1, 30-32 cm) at a depth of $107 \mathrm{mbsf}$, has a relatively high $\mathrm{V}_{p}=5.88 \mathrm{~km} / \mathrm{s}$. Two massive pyrite breccias, plotted in Figure 3 (Samples 957H-5N-1, 4-6 cm, and 957P-6R-1, 11-13 cm), were both recovered at about $27 \mathrm{mbsf}$ and cannot be classified in any of the four major zones.

Extremely difficult drilling conditions prevented special downhole and logging tool deployments during Leg 158. Shipboard physical properties measurements are the only geophysical data available for rocks from a sediment-free subsurface hydrothermal system. However, shipboard minicore velocity measurements provide only $V_{p}$ data at atmospheric pressures and do not represent the in situ properties of the rocks. The ultrasonic high-pressure data for the TAG-1 and TAG-5 samples, shown in Figures 4 and 5, illustrate the improvement achieved over the original shipboard measurements using the same samples. Although shipboard $V_{p}$ data seem widely scattered, the ultrasonic measurements indicate a general velocity increase with depth. A possible explanation for this trend is the increasing cementation and silicification from sulfides to silicified wallrock breccias with depth observed throughout the mound.

Two samples from TAG-1 (Samples 957C-7N-2, 114-116 cm, and $957 \mathrm{C}-7 \mathrm{~N}-3,15-17 \mathrm{~cm}$ ) were removed from massive anhydrite veins. Shipboard measurements on these samples were unsuccessful because of energy attenuation caused by the relatively frail make-up of the samples. However, clear signals were recorded during the ultrasonic measurements at all confining pressures $\geq 20 \mathrm{MPa}$ despite the instability of anhydrite when seawater-saturated (Table 3 ). The compressional-wave velocities at $100 \mathrm{MPa}$ were 4.8 and $4.4 \mathrm{~km} / \mathrm{s}$, respectively (Fig. 4). These values are considerably higher (22\%-33\%) than a comparable reference value of $V_{p}=3.6 \mathrm{~km} / \mathrm{s}$ for an anhydrite specimen from the Swiss Alps (Clark, 1966), perhaps because of traces of massive sulfide clasts present in the TAG samples (Table 2).

Compressional-wave velocity at $100 \mathrm{MPa}$ is plotted vs. bulk density for all samples in Figure 6. As expected, a general trend of increasing velocities with increasing densities can be observed. This trend is especially obvious for the anhydrite-rich samples of Zone 2: the almost pure anhydrite vein sample with a low velocity of $4.4 \mathrm{~km} /$ $\mathrm{s}$ also has a low bulk density of $2.8 \mathrm{~g} / \mathrm{cm}^{3}$ and a grain density of 3.0 $\mathrm{g} / \mathrm{cm}^{3}$. (A grain density of $3.0 \mathrm{~g} / \mathrm{cm}^{3}$ is also given for the anhydrite mineral by Clark [1966]). The other extreme is a massive pyriteanhydrite breccia sample (Sample 957G-3N-1, 12-14 cm) with $V_{p}=$ $6.3 \mathrm{~km} / \mathrm{s}$ and a bulk density of $4.1 \mathrm{~g} / \mathrm{cm}^{3}$. On the other hand, the three altered basalt samples from TAG- 4 have an average bulk density of $2.88 \mathrm{~g} / \mathrm{cm}^{3}$, and their average compressional-wave velocity at 100 $\mathrm{MPa}$ is $6 \mathrm{~km} / \mathrm{s}$.

Compressional-wave velocity at $100 \mathrm{MPa}$ is plotted vs. total porosity, calculated from index properties measurements for all minicore samples in Figure 7. A trend is visible only for the anhydrite-rich rocks of Zone 2, where, in general, seismic velocity decreases with increasing total porosity. For the other samples, the seismic velocity vs. total porosity relationship is widely scattered. Wilkens et al. (1991) and Berge et al. (1992) have shown that the porosity distribution-pore-shape relationship is a more useful quantity than total porosity. A more detailed discussion follows in the "Porosity Models" section (this chapter).

\section{DISCUSSION}

\section{Seismic Velocities and Porosity Structure}

The results of the ultrasonic experiments for samples from the TAG-1, TAG-2, and TAG-5 areas are shown in Figures 8, 9, and 10, respectively. In general, a substantial increase in velocities is recorded between 5 and $15 \mathrm{MPa}$. At higher pressures, both compressionalwave velocities and shear-wave velocities increase steadily. Silicified wallrock breccia samples from both the TAG-1 and the TAG-2 areas show steeply increasing velocity vs. pressure curves, whereas a massive granular pyrite sample from TAG-2 and two pyrite-silica breccias from TAG-5 have much "flatter" curves. The application of increasing confining pressure during measurements reduces the aperture of drilling-related cracks and some endemic cracks, so that both compressional-wave velocities and shear-wave velocities increase as porosity effects decrease (Wilkens et al., 1991).

In recent studies by Iturrino et al. (1995) and Johnston et al. (1995), it has been suggested that thin cracks may result from a reduction of confining pressure, as rocks are recovered from the seafloor and brought to atmospheric pressure. Johnston et al. (1995) made this observation for low-porosity basalts with a low population of microcracks. The low permeability of these rocks prevents the rapid loss of pressure from seawater-saturated pore spaces, thereby significantly increasing the pore pressure required for cracking to occur as the confining pressure decreases. This effect, however, is insignificant for the sulfide-rich samples from the TAG mound, because their relatively high porosity and permeability prevent pore fluid overpressuring. Microscopic analyses of the TAG samples suggest that the thin cracks and vesicular pore spaces present are probably in situ properties of those rocks, because no radial cracking, typical of pore fluid overpressuring (Johnston et al., 1995), was observed in thin sections. The effect of different pore shapes on the measured seismic velocities is discussed later.

Compressional-wave velocities are plotted vs. average shearwave velocities in Figure 11, along with lines of constant $V_{p} / V_{s}$ ratio. Rock types of the different zones have distinct characteristics. Two of the massive sulfides near the surface of the mound have a high $V_{p} / V_{s}$ ratio of 1.8 to 1.9. Anhydrite-rich samples exhibit medium to high values ranging from 1.65 to 1.85 . The more silicified samples of Zone 3 , as well as the chloritized basalt sample of Zone 4, plot on lines of low $V_{p} / V_{s}$, narrowly ranging from 1.55 to 1.6 for seven out of eight samples, with the remaining sample only slightly higher at 1.65 . Although increased silicification of the different rock types with depth increases compressional-wave velocities (Figs. 4, 5), the shear-wave velocities are less affected. In terms of porosity structure, these relatively high shear-wave velocities can be explained by a high concentration of large aspect ratio pore spaces (e.g., vesicles) rather than a high concentration of small aspect ratio voids (e.g., thin cracks), because vesicular pore spaces will reduce shear-wave velocities much less than thin cracks (Wilkens et al., 1991).

For most samples, the velocities of the two orthogonal shear waves $S 1$ and $S 2$ are indistinguishable (Table 3), confirming visual and microscopic observations that indicate random rather than preferred orientation of both minerals and void spaces. However, the nature of this study can only detect variations at the hand-sample scale and, although large-scale anisotropy might exist within the mound, no inferences can be made owing to the lack of any other kind of seismic data.

\section{Sulfides}

An exception to the near-equality of shear-wave velocities for the two orthogonally propagating shear waves $S 1$ and $S 2$ can be observed for the massive sulfide samples found in the upper few meters of the mound (Zone 1), which is illustrated in Figure 12. Two massive sulfide samples from the TAG-1 area have significantly lower $S 2$ than $S 1$ velocities. Those samples were recovered from Hole 957F in relatively close proximity of the active Black Smoker Complex. Because these samples are oriented, propagation of $S 2$ waves is in the plane parallel to the drill core axis (Fig. 2). The distinct orientational preference might be explained by the location of those samples near the major upflow conduit (Fig. 1). A massive sulfide sample recov- 


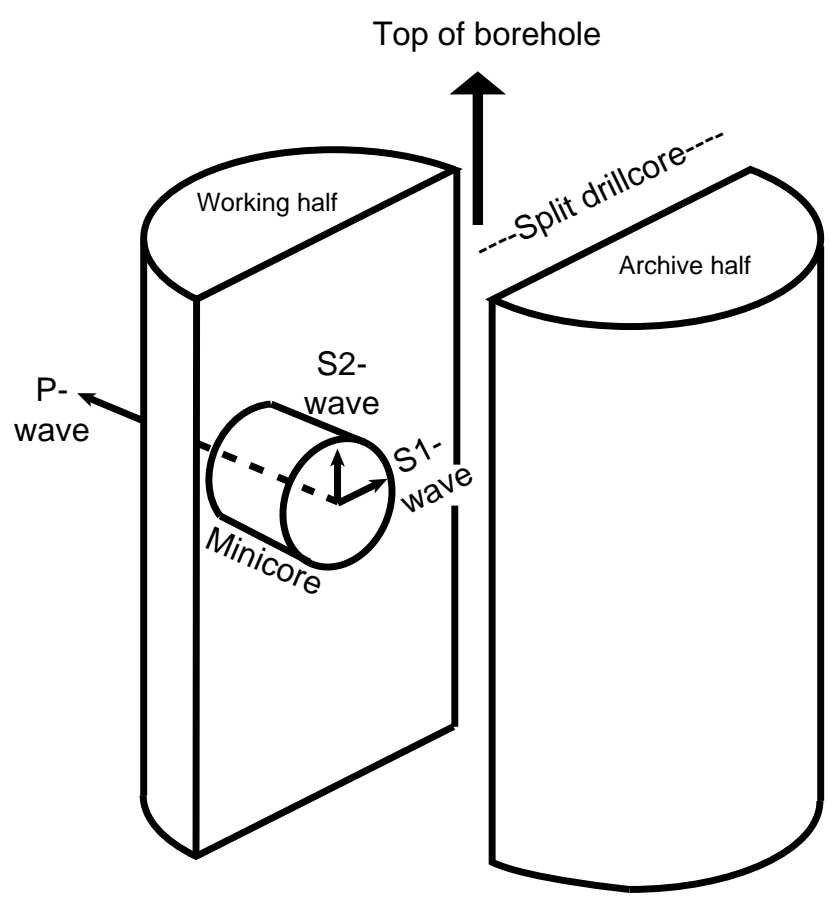

Figure 2. Geometry of ultrasonic measurements on minicore samples extracted from the working half of the split drillcore. A compressional wave propagates along the vertical axis of the minicore in a plane parallel to the seafloor. Two orthogonal shear waves, $S 1$ and $S 2$, travel through the sample such that $S 2$ propagates in the plane parallel to the borehole axis, and $S 1$ propagates perpendicular to the borehole axis.

ered at TAG-2 (Sample 957N-1W-1, 62-64 cm) shows the opposite effect of having a higher $S 2$ than $S 1$ velocity. The TAG-2 area located near the "Kremlin" area represents a very different hydrothermal regime than at TAG-1. One other massive sulfide sample from the TAG-5 area (Sample 957O-2R-1, 34-36 cm), at the northern side of the actively venting Black Smoker Complex, does not exhibit any preferred orientation for shear wave propagation. These anisotropic shear-wave velocity observations must, however, be interpreted with caution, because too few of the massive sulfide samples were available for the seismic velocity measurements.

Compressional-wave velocities are presented as a function of sulfide mineral percentage in Figure 13. An increase in $V_{p}$ with increasing concentration of the major sulfide minerals (i.e., pyrite and chalcopyrite) can be observed for all samples from Zone 2 and 3, because of the high bulk moduli of the principal mineral constituents (Table 2).

\section{Sulfates}

The abundance of anhydrite preserved within the mound (estimated to be in the order of $10^{5} \mathrm{~m}^{3}$ ) was unexpected (Humphris et al., 1995). Compressional-wave velocities as a function of anhydrite concentration are shown in Figure 14. Seismic velocities of the anhydrite-rich samples of Zone 2 are substantially affected by the abundance of the sulfate mineral. With increasing anhydrite concentration, $V_{p}$ decreases linearly. Microscopic observations of some of the samples plotted in Figure 14 show that with an increase in anhydrite concentration, concentration of thin cracks and vesicular pore spaces also increases. Both effects, the relatively low bulk moduli of anhydrite and the increase in small aspect ratio pore spaces, are the cause of this observed velocity/anhydrite concentration dependence.

Another characteristic of the sulfate-rich samples is illustrated in Figure 15 . As increasing confining pressures were applied to anhy- drite Sample 957C-7N-3, 15-17 cm, some cracks closed, but only partially reopened after pressures were reduced, resulting in velocity hysteresis between 5 and $20 \mathrm{MPa}$. A detailed explanation for such a $V_{p}$ hysteresis was given by (Iturrino et al., 1991). Although other measurements, consisting of increasing and decreasing pressure cycles, were performed for all major rock types, only the anhydriteenriched samples of Zone 2 showed this hysteresis behavior.

\section{Basalts}

Drilling into basalt with different degrees of alteration may indicate the horizontal and vertical dimensions of the mineralized upflow zone. Three altered basalt samples were recovered over a depth range of 43-47 mbsf at TAG-4, Hole 957M, west of the Black Smoker Complex, and a chloritized basalt breccia was recovered at a depth of 107 mbsf at TAG-1, Hole 957E. Although similar in appearance, the basalts have distinctive characteristics associated with different degrees of alteration and variable porosity structure. Basalts from TAG4 are altered, have low porosity $(\Phi=1.2 \%-1.7 \%)$ and compressional-wave velocities that increase from about $5.9 \mathrm{~km} / \mathrm{s}$ at $5 \mathrm{MPa}$ to 6.1 $\mathrm{km} / \mathrm{s}$ at $100 \mathrm{MPa}$. Shear-wave velocities increase from about $3.3 \mathrm{~km} /$ $\mathrm{s}$ at $5 \mathrm{MPa}$ to $3.4 \mathrm{~km} / \mathrm{s}$ at $100 \mathrm{MPa}$. On the other hand, the relatively high-porosity ( $\Phi=3.5 \%$ ), chloritized basalt sample from TAG-1 shows an increase in compressional-wave velocity from 5.3 to 5.9 $\mathrm{km} / \mathrm{s}$ and an increase in shear-wave velocity from 3.2 to $3.8 \mathrm{~km} / \mathrm{s}$ at $5 \mathrm{MPa}$ and $100 \mathrm{MPa}$, respectively. These distinctive velocity vs. pressure ratios for basalt samples from different parts of the TAG mound indicate a strong dependence on the porosity structure, which is confirmed by thin-section analysis and visual observations (Table 2 ): the TAG-4 basalts contain only small concentrations of thin, small aspect ratio cracks, whereas the TAG-1 basalts contain many thin cracks that close during the increasing pressure cycle.

Christensen and Salisbury (1975) compared compressional-wave velocities and densities for 77 seafloor basalts and suggested a nonlinear relationship between these parameters. For "normal" seafloor basalts, their model predicts a compressional-wave velocity of 6.37 $\mathrm{km} / \mathrm{s}$ for a given density of $2.88 \mathrm{~g} / \mathrm{cm}^{3}$. For TAG basalts with similar densities, $V_{p}$ is less than $6.1 \mathrm{~km} / \mathrm{s}$ and the total porosity of $1.2 \%-1.7 \%$ is low. Microscopic analysis shows few unfilled pore spaces, and the few observed void spaces are predominantly vesicular (Table 2). However, the samples have a framework composed of altered grains. A low concentration of large aspect ratio pore spaces (e.g., vesicles) will cause only a negligible reduction in compressional-wave velocity (e.g., Ludwig et al., in press; Shearer and Orcutt, 1985; Wilkens et al., 1991). The deviation from "normal" basalt velocities can therefore be explained as a direct result of hydrothermal alteration, rather than porosity effects.

\section{POROSITY MODELS}

Understanding the porosity structure of an active hydrothermal system is essential for describing both present and past episodes of hydrothermal activity. Models dealing with fluid flow, geochemical fluxes, and alteration mechanisms would greatly benefit from constraints on the pore shape concentration of the different rock types encountered during drilling of the active TAG hydrothermal mound.

\section{Background}

The velocities of seismic waves traveling through a rock are affected by the rock's porosity, the shape of its pores, and the media filling the pores. To infer porosity and pore shape from seismic velocities requires a theory relating these different properties, but as Berge et al. (1992) show, no theory is completely adequate for the high porosities and broad range of pore shapes present in subseafloor 
Table 3. Compressional-wave and shear-wave velocities for sulfide, sulfate, and basalt samples from the TAG active mound.

\begin{tabular}{|c|c|c|c|c|c|c|c|c|c|c|c|c|c|c|c|c|}
\hline \multirow{2}{*}{$\begin{array}{l}\text { Core, section, } \\
\text { interval }(\mathrm{cm})\end{array}$} & \multirow{2}{*}{$\begin{array}{l}\text { Depth } \\
\text { (mbsf) }\end{array}$} & \multirow[b]{2}{*}{ Rock type } & \multirow{2}{*}{$\begin{array}{c}\text { Velocity } \\
(\mathrm{km} / \mathrm{s})\end{array}$} & \multicolumn{12}{|c|}{ Pressure (MPa) } & \multirow{2}{*}{$\begin{array}{l}\text { Oriented } \\
\text { sample }\end{array}$} \\
\hline & & & & 5 & 10 & 15 & 20 & 30 & 40 & 50 & 60 & 70 & 80 & 90 & 100 & \\
\hline \multicolumn{17}{|c|}{ TAG-1 (East of Black Smoker Complex) } \\
\hline \multirow{3}{*}{$\begin{array}{r}15-95 / C- \\
7 \mathrm{~N}-2,8-10\end{array}$} & 20.93 & Nodular silicified pyrite-anhydrite breccia & $V_{m}$ & 4.76 & 4.85 & 4.90 & 5.05 & 5.09 & 5.13 & 5.15 & 5.19 & 5.20 & 5.25 & 5.26 & 5.30 & Yes \\
\hline & & & $V_{s l}^{p}$ & $\begin{array}{l}4.10 \\
2.62\end{array}$ & $\begin{array}{l}2.03 \\
2.66\end{array}$ & 2.75 & 2.80 & 2.88 & 2.94 & 3.02 & 3.08 & 3.11 & 3.13 & 3.14 & 3.16 & \\
\hline & & & $V_{s 2}^{T}$ & 2.71 & 2.72 & 2.77 & 2.82 & 2.97 & 3.03 & 3.10 & 3.12 & 3.15 & 3.16 & 3.17 & 3.18 & \\
\hline \multirow{3}{*}{$7 \mathrm{~N}-2,114-116$} & 21.99 & Anhydrite vein & $V_{p}^{s}$ & 3.94 & 3.92 & & 4.17 & 4.49 & 4.52 & 4.56 & 4.58 & 4.60 & 4.66 & 4.72 & 4.80 & Yes \\
\hline & & & $V_{s 1}^{\prime}$ & 2.61 & 3.05 & & 3.11 & 2.39 & 2.40 & 2.40 & 2.42 & 2.45 & 2.48 & 2.51 & 2.55 & \\
\hline & & & $V_{s 2}$ & 2.55 & 4.79 & & 3.13 & 2.34 & 2.36 & 2.41 & 2.43 & 2.46 & 2.48 & 2.52 & 2.56 & \\
\hline \multirow{3}{*}{$7 \mathrm{~N}-3,15-17$} & 22.50 & Anhydrite vein & $V_{p}$ & $3.82 *$ & $3.86^{*}$ & $3.90^{*}$ & 3.79 & 3.93 & 4.06 & 4.13 & 4.21 & 4.27 & 4.31 & 4.39 & 4.42 & Yes \\
\hline & & & $V_{s 1}^{\prime}$ & $1.87^{*}$ & $2.09^{*}$ & $2.14 *$ & 2.10 & 2.21 & 2.31 & 2.34 & 2.43 & 2.48 & 2.50 & 2.53 & 2.55 & \\
\hline & & & $V_{s 2}^{11}$ & $1.96^{*}$ & $2.05^{*}$ & $2.11 *$ & 2.10 & 2.22 & 2.31 & 2.37 & 2.39 & 2.44 & 2.49 & 2.49 & 2.51 & \\
\hline \multirow[t]{3}{*}{$11 \mathrm{~N}-3,118-120$} & 34.79 & Pyrite-silica breccia & $V_{p}^{2}$ & 5.16 & 5.23 & 5.29 & 5.31 & 5.36 & 5.40 & 5.42 & 5.44 & 5.46 & 5.49 & 5.51 & 5.52 & Yes \\
\hline & & & $\vec{v}_{s 1}$ & 3.12 & 3.16 & 3.20 & 3.24 & 3.28 & 3.32 & 3.35 & 3.38 & 3.40 & 3.41 & 3.42 & 3.43 & \\
\hline & & & $\begin{array}{lll}s t \\
V_{s 2}\end{array}$ & 3.16 & 3.21 & 3.26 & 3.31 & 3.35 & 3.39 & 3.40 & 3.42 & 3.44 & 3.45 & 3.47 & 3.48 & \\
\hline \multirow[t]{3}{*}{$15 \mathrm{~N}-1,115-117$} & 43.35 & Silicified wallrock breccia & $V_{p}^{s}$ & 5.16 & 5.23 & 5.38 & 5.40 & 5.45 & 5.53 & 5.56 & 5.60 & 5.63 & 5.66 & 5.70 & 5.72 & Yes \\
\hline & & & $\vec{v}_{s l}^{p}$ & 2.94 & 3.02 & 3.11 & 3.18 & 3.25 & 3.30 & 3.35 & 3.41 & 3.43 & 3.45 & 3.47 & 3.50 & \\
\hline & & & $\begin{array}{l}v_{s 1} \\
V_{s 2}\end{array}$ & 2.80 & 2.85 & 3.03 & 3.08 & 3.25 & 3.34 & 3.40 & 3.45 & 3.49 & 3.51 & 3.54 & 3.55 & \\
\hline $16 \mathrm{~N}-1,35-37$ & 46.55 & Nodular pyrite-silica breccia & $V_{p}^{s}$ & 5.21 & 5.26 & 5.27 & 5.29 & 5.33 & 5.41 & 5.45 & 5.48 & 5.51 & 5.53 & 5.56 & 5.58 & Yes \\
\hline & & & $V_{s 1}$ & 3.03 & 3.15 & 3.20 & 3.31 & 3.40 & 3.46 & 3.48 & 3.50 & 3.52 & 3.55 & 3.57 & 3.58 & \\
\hline & & & $V_{s 2}$ & 3.11 & 3.16 & 3.33 & 3.34 & 3.47 & 3.47 & 3.48 & 3.51 & 3.53 & 3.55 & 3.57 & 3.58 & \\
\hline 158-957E- & & & & & & & & & & & & & & & & \\
\hline $8 \mathrm{R}-1,10-12$ & 72.90 & Silicified wallrock breccia & $V_{p}$ & 5.37 & 5.39 & 5.45 & 5.50 & 5.56 & 5.60 & 5.62 & 5.63 & 5.69 & 5.69 & 5.71 & 5.72 & No \\
\hline & & & $V_{s 1}$ & 3.21 & 3.35 & 3.38 & 3.41 & 3.48 & 3.49 & 3.52 & 3.53 & 3.56 & 3.57 & 3.59 & 3.61 & \\
\hline & & & $V_{s 2}^{V_{s}}$ & 3.17 & 3.36 & 3.38 & 3.39 & 3.49 & 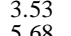 & 3.54 & 3.58 & 3.61 & 3.62 & 3.63 & 3.65 & \\
\hline $15 \mathrm{R}-1,30-32$ & 106.80 & Chloritized basalt breccia & $V_{p}$ & $\begin{array}{r}5.29 \\
3.20\end{array}$ & 5.38 & 5.50 & $\begin{array}{l}5.53 \\
3.46\end{array}$ & 5.61 & $\begin{array}{l}5.68 \\
3.58\end{array}$ & $\begin{array}{r}5.73 \\
3.62\end{array}$ & 5.78 & 5.81 & 5.83 & 5.85 & 5.88 & No \\
\hline & & & $\begin{array}{l}V_{s 1} \\
V_{s 2}\end{array}$ & 3.29 & 3.34 & 3.42 & 3.47 & 3.53 & 3.59 & $\begin{array}{l}3.02 \\
3.66\end{array}$ & $\begin{array}{l}3.00 \\
3.69\end{array}$ & 3.70 & 3.73 & 3.75 & 3.78 & \\
\hline $158-957 \mathrm{~F}$ & & & & & & & & & & & & & & & & \\
\hline $1 \mathrm{~N}-1,62-64$ & 1.62 & Massive pyrite breccia & $\begin{array}{l}V_{p} \\
V_{u}\end{array}$ & $\begin{array}{l}5.17 \\
2.75\end{array}$ & $\begin{array}{l}5.18 \\
2.75\end{array}$ & $\begin{array}{l}5.21 \\
2.76\end{array}$ & $\begin{array}{l}5.22 \\
2.77\end{array}$ & $\begin{array}{l}5.23 \\
2.77\end{array}$ & $\begin{array}{l}5.25 \\
280\end{array}$ & $\begin{array}{l}5.28 \\
2.80\end{array}$ & $\begin{array}{l}5.30 \\
2.83\end{array}$ & $\begin{array}{l}5.25 \\
2.83\end{array}$ & 5.26 & $\begin{array}{l}5.27 \\
286\end{array}$ & $\begin{array}{l}5.30 \\
2.88\end{array}$ & Yes \\
\hline & & & $\begin{array}{lll}s t \\
V_{s 2}\end{array}$ & 2.73 & 2.73 & 2.75 & 2.76 & 2.78 & 2.80 & 2.82 & 2.82 & 2.82 & 2.83 & 2.83 & 2.84 & \\
\hline $1 \mathrm{~N}-1,71-73$ & 1.71 & Massive pyrite breccia & $V_{p}^{2}$ & 5.63 & 5.58 & 5.67 & 5.68 & 5.70 & 5.71 & 5.73 & 5.74 & 5.76 & 5.77 & 5.77 & 5.79 & Yes \\
\hline & & & $V_{s 1}^{\prime}$ & 3.21 & 3.21 & 3.25 & 3.33 & 3.34 & 3.34 & 3.35 & 3.35 & 3.36 & 3.35 & 3.26 & 3.27 & \\
\hline & & & $V_{s 2}$ & 3.12 & 3.03 & 3.10 & 3.11 & 2.98 & 3.01 & 3.07 & 3.07 & 3.07 & 3.06 & 3.07 & 3.07 & \\
\hline $158-957 \mathrm{G}-$ & & & & & & & & & & & & & & & & \\
\hline $3 \mathrm{~N}-1,12-14$ & 21.12 & Massive pyrite-anhydrite breccia & $V_{p}$ & 6.01 & 6.05 & 6.10 & 6.12 & 6.15 & 6.17 & 6.18 & 6.20 & 6.21 & 6.23 & 6.25 & 6.26 & Yes \\
\hline & & & $V_{s 1}$ & 3.6 & 3.66 & 3.7 & 3.7 & 3.7 & 3. & 3.8 & 3. & 3. & 3. & 3. & 3. & \\
\hline TAG-2 (Kremlin A & & & $V_{s 2}$ & 3.63 & 3.75 & 3.72 & 3.77 & 3.78 & 3.80 & 3.81 & 3.81 & 3.82 & 3.83 & 3.83 & 3.85 & \\
\hline $158-957 \mathrm{H}-$ & & & & & & & & & & & & & & & & \\
\hline $5 N-1,4-6$ & 26.74 & Massive granular pyrite & $V_{p}$ & 6.66 & 6.68 & 6.68 & 6.68 & 6.70 & 6.72 & 6.74 & 6.74 & 6.74 & 6.76 & 6.78 & 6.80 & Yes \\
\hline & & & $V_{s l}$ & 4.05 & $\begin{array}{l}4.09 \\
412\end{array}$ & 4.11 & 4.14 & $\begin{array}{l}4.16 \\
415\end{array}$ & $\begin{array}{l}4.18 \\
416\end{array}$ & $\begin{array}{l}4.19 \\
417\end{array}$ & $\begin{array}{r}4.20 \\
418\end{array}$ & $\begin{array}{l}4.21 \\
419\end{array}$ & 4.21 & 4.22 & 4.23 & \\
\hline $5 \mathrm{~N}-2,29-31$ & 27.89 & Silicified wallrock breccia & $\begin{array}{l}V_{s 2} \\
V_{p}\end{array}$ & $\begin{array}{l}4.04 \\
6.32\end{array}$ & $\begin{array}{l}4.12 \\
6.39\end{array}$ & $\begin{array}{l}4.13 \\
6.47\end{array}$ & $\begin{array}{l}4.13 \\
6.54\end{array}$ & $\begin{array}{l}4.15 \\
6.64\end{array}$ & $\begin{array}{l}4.16 \\
6.68\end{array}$ & $\begin{array}{l}4.17 \\
6.76\end{array}$ & $\begin{array}{l}4.18 \\
6.78\end{array}$ & $\begin{array}{l}4.19 \\
6.80\end{array}$ & $\begin{array}{l}4.19 \\
6.82\end{array}$ & $\begin{array}{l}4.20 \\
6.84\end{array}$ & $\begin{array}{l}4.22 \\
6.86\end{array}$ & Yes \\
\hline & & & $\overrightarrow{V_{s 1}}$ & 3.43 & 3.44 & 3.60 & 3.67 & 4.10 & 4.14 & 4.15 & 4.16 & 4.16 & 4.17 & 4.19 & 4.20 & \\
\hline & & & $V_{s 2}$ & 3.54 & 3.74 & 3.78 & 3.92 & 4.10 & 4.13 & 4.14 & 4.14 & 4.15 & 4.16 & 4.17 & 4.18 & \\
\hline $158-957 \mathrm{~N}-$ & & & & & & & & & & & & & & & & \\
\hline $1 \mathrm{~W}-1,62-64$ & 0.62 & Nodular pyrite-silica breccia & $V_{p}$ & 5.25 & 5.26 & 5.31 & 5.35 & 5.39 & 5.46 & 5.49 & 5.50 & 5.52 & 5.53 & 5.55 & 5.57 & No \\
\hline & & & $V_{s}$ & 2.9 & 3.1 & 3.2 & 3.2 & 3.2 & 3. & 3. & 3.4 & 3. & 3. & 3.4 & 3.4 & \\
\hline & & & $V_{s 2}$ & 2.76 & 3.02 & 3.19 & 3.24 & 3.37 & 3.44 & 3.48 & 3.50 & 3.51 & 3.51 & 3.52 & 3.53 & \\
\hline $\begin{array}{l}\text { TAGG-4 (West of BI } \\
158-957 \mathrm{M}-\end{array}$ & Smoker C & mplex) & & & & & & & & & & & & & & \\
\hline $9 \mathrm{R}-1,61-63$ & 42.91 & Altered basalt & $V_{p}$ & 5.89 & 5.92 & 5.93 & 5.94 & 5.96 & 5.99 & 6.00 & 6.01 & 6.03 & 6.04 & 6.06 & 6.07 & Yes \\
\hline & & & $V_{s 1}$ & 3.21 & 3.24 & 3.25 & 3.26 & 3.26 & 3.27 & 3.29 & 3.30 & 3.33 & 3.33 & 3.34 & 3.35 & \\
\hline & & & $V_{s 2}$ & 2.88 & 3.16 & 3.17 & 3.18 & 3.24 & 3.25 & 3.28 & 3.31 & 3.34 & 3.34 & 3.36 & 3.36 & \\
\hline 10R-1,39-41 & 46.59 & Altered basalt & $V_{p}$ & 5.98 & 5.99 & 6.01 & 6.01 & 6.02 & 6.04 & 6.04 & 6.06 & 6.06 & 6.06 & 6.06 & 6.06 & Yes \\
\hline & & & & 3.32 & 3.35 & 3.39 & 3.39 & 3.38 & 3.38 & 3.38 & 3.39 & 3.39 & 3.40 & 3.40 & 3.41 & \\
\hline & & & $V_{s 2}$ & 3.37 & 3.37 & 3.38 & 3.38 & 3.37 & 3.38 & 3.38 & 3.39 & 3.39 & 3.40 & 3.40 & 3.40 & \\
\hline $10 \mathrm{R}-1,47-49$ & 46.67 & Altered basalt & $V_{p}$ & 5.89 & 5.91 & 5.95 & 5.97 & 5.97 & 5.97 & 5.97 & 5.99 & 5.99 & 5.99 & 5.99 & 6.00 & No \\
\hline & & & 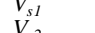 & 3.32 & 3.32 & 3.39 & 3.40 & 3.41 & 3.41 & 3.41 & 3.41 & 3.41 & 3.41 & 3.41 & 3.41 & \\
\hline & & & $V_{s 2}$ & 3.31 & 3.32 & 3.46 & 3.46 & 3.46 & 3.41 & 3.42 & 3.43 & 3.43 & 3.43 & 3.42 & 3.43 & \\
\hline
\end{tabular}


Table 3 (continued).

\begin{tabular}{|c|c|c|c|c|c|c|c|c|c|c|c|c|c|c|c|c|}
\hline \multirow{2}{*}{$\begin{array}{l}\text { Core, section, } \\
\text { interval }(\mathrm{cm})\end{array}$} & \multirow{2}{*}{$\begin{array}{l}\text { Depth } \\
\text { (mbsf) }\end{array}$} & \multirow[b]{2}{*}{ Rock type } & \multirow{2}{*}{$\begin{array}{l}\text { Velocity } \\
(\mathrm{km} / \mathrm{s})\end{array}$} & \multicolumn{12}{|c|}{ Pressure (MPa) } & \multirow{2}{*}{$\begin{array}{l}\text { Oriented } \\
\text { sample }\end{array}$} \\
\hline & & & & 5 & 10 & 15 & 20 & 30 & 40 & 50 & 60 & 70 & 80 & 90 & 100 & \\
\hline \multicolumn{17}{|c|}{ TAG-5 (North of Black Smoker Complex) } \\
\hline \multirow{3}{*}{$\begin{array}{l}158-9570- \\
2 \mathrm{R}-1,34-36\end{array}$} & 8.24 & Nodular pyrite breccia & $V_{p}$ & 5.28 & 5.39 & 5.46 & 5.49 & 5.59 & 5.61 & 5.62 & 5.67 & 5.67 & 5.69 & 5.73 & 5.74 & Yes \\
\hline & & 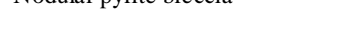 & $V_{s l}^{p}$ & 2.80 & 2.86 & 2.99 & 3.07 & 3.23 & 3.25 & 3.29 & 3.32 & 3.34 & 3.36 & 3.36 & 3.38 & \\
\hline & & & $V_{8} T$ & 2.94 & 2.99 & 3.13 & 3.21 & 3.28 & 3.29 & 3.32 & 3.34 & 3.36 & 3.37 & 3.38 & 3.39 & \\
\hline \multirow[t]{3}{*}{$4 \mathrm{R}-1,19-21$} & 16.09 & Pyrite-anhydrite breccia & $V_{p}$ & 5.64 & 5.85 & 5.96 & 5.97 & 6.06 & 6.12 & 6.13 & 6.15 & 6.16 & 6.18 & 6.19 & 6.21 & Yes \\
\hline & & & $V_{s l}$ & 2.95 & 3.10 & 3.24 & 3.24 & 3.31 & 3.37 & 3.40 & 3.45 & 3.48 & 3.50 & 3.54 & 3.55 & \\
\hline & & & $V_{s 2}^{i t}$ & 2.75 & 2.89 & 3.03 & 3.05 & 3.09 & 3.10 & 3.30 & 3.36 & 3.40 & 3.43 & 3.45 & 3.47 & \\
\hline \multirow[t]{3}{*}{$4 \mathrm{R}-1,29-31$} & 16.19 & Nodular pyrite-anhydrite breccia & $V_{p}$ & 5.74 & 5.78 & 5.81 & 5.84 & 5.88 & 5.94 & 5.97 & 5.98 & 6.01 & 6.03 & 6.06 & 6.07 & Yes \\
\hline & & & $V_{s l}^{\prime}$ & 3.18 & 3.21 & 3.26 & 3.29 & 3.33 & 3.38 & 3.39 & 3.41 & 3.42 & 3.44 & 3.47 & 3.51 & \\
\hline & & & $V_{s 2}^{s i}$ & 2.99 & 3.08 & 3.16 & 3.27 & 3.27 & 3.34 & 3.42 & 3.44 & 3.47 & 3.49 & 3.50 & 3.53 & \\
\hline \multirow{4}{*}{$\begin{array}{l}\text { 158-957P- } \\
1 \mathrm{R}-1,49-51\end{array}$} & & & & & & & & & & & & & & & & \\
\hline & 0.49 & Pyrite-anhydrite breccia & $V_{p}$ & 4.69 & 4.77 & 4.78 & 4.79 & 4.81 & 4.85 & 4.88 & 4.90 & 4.91 & 4.93 & 4.96 & 4.98 & Yes \\
\hline & & & $V_{u}^{\prime \prime}$ & 2.53 & 2.62 & 2.66 & 2.69 & 2.72 & 2.74 & 2.76 & 2.77 & 2.77 & 2.78 & 2.78 & 2.79 & \\
\hline & & & $V_{s 2}$ & 2.54 & 2.54 & 2.59 & 2.61 & 2.68 & 2.70 & 2.72 & 2.73 & 2.74 & 2.74 & 2.75 & 2.76 & \\
\hline \multirow[t]{3}{*}{$6 \mathrm{R}-1,11-13$} & 26.61 & Nodular pyrite breccia & $V_{p}^{2 \alpha}$ & 5.74 & 5.80 & 5.84 & 5.92 & 5.96 & 5.99 & 6.02 & 6.04 & 6.06 & 6.08 & 6.10 & 6.13 & Yes \\
\hline & & & $V_{s l}^{p}$ & 3.36 & 3.45 & 3.52 & 3.55 & 3.59 & 3.64 & 3.68 & 3.71 & 3.72 & 3.74 & 3.74 & 3.76 & \\
\hline & & & $V_{s 2}$ & 3.43 & 3.46 & 3.50 & 3.51 & 3.56 & 3.58 & 3.59 & 3.61 & 3.63 & 3.68 & 3.68 & 3.70 & \\
\hline \multirow{3}{*}{$9 \mathrm{R}-1,4-6$} & 40.14 & Nodular pyrite-silica breccia & $V_{p}$ & 5.62 & 5.66 & 5.69 & 5.70 & 5.74 & 5.77 & 5.78 & 5.78 & 5.80 & 5.81 & 5.82 & 5.84 & Yes \\
\hline & & & $V_{s l}$ & 3.02 & 3.63 & 3.71 & 3.75 & 3.75 & 3.76 & 3.76 & 3.76 & 3.77 & 3.77 & 3.78 & 3.79 & \\
\hline & & & $V_{s 2}$ & 3.06 & 3.56 & 3.65 & 3.67 & 3.71 & 3.72 & 3.74 & 3.74 & 3.75 & 3.76 & 3.76 & 3.77 & \\
\hline \multirow{3}{*}{$12 \mathrm{R}-2,67-69$} & 56.31 & Pyrite-silica breccia & $V_{p}^{2-}$ & 6.52 & 6.61 & 6.63 & 6.67 & 6.69 & 6.71 & 6.72 & 6.74 & 6.74 & 6.74 & 6.76 & 6.76 & Yes \\
\hline & & & $V_{s l}^{\prime}$ & 4.04 & 4.07 & 4.07 & 4.09 & 4.12 & 4.15 & 4.15 & 4.16 & 4.17 & 4.18 & 4.18 & 4.19 & \\
\hline & & & $V_{s 2}^{\prime \prime}$ & 4.13 & 4.10 & 4.13 & 4.14 & 4.18 & 4.19 & 4.20 & 4.21 & 4.22 & 4.22 & 4.22 & 4.23 & \\
\hline
\end{tabular}

Note: Ultrasonic measurements were made at increasing confining pressures of 5 to $100 \mathrm{MPa}$ at the Petrophysics Laboratory of the Rosenstiel School of Marine and Atmospheric Science (RSMAS), University of Miami. * = exceptions in measurement sequence (see text for description). 
Compressional-wave velocity $(\mathrm{km} / \mathrm{s})$

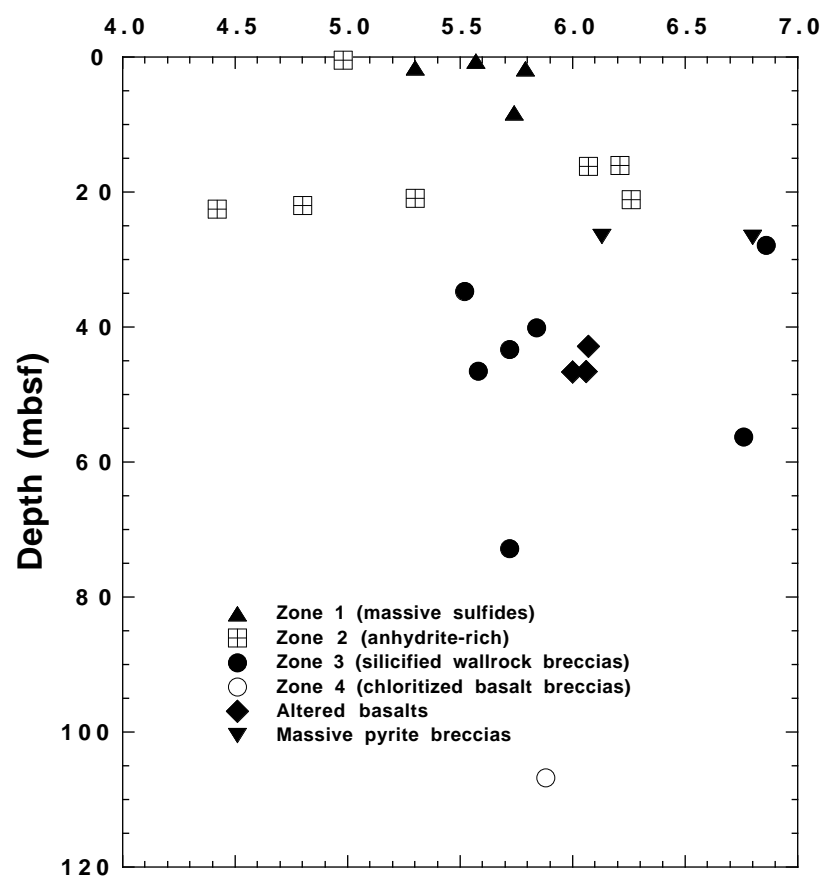

Figure 3. Variations of compressional-wave velocities measured at $100 \mathrm{MPa}$ vs. depth for the 24 minicore samples. The plot symbols correspond to the major internal structural zones of the active TAG mound, shown in the legend.

rocks. Two broad groups of theories describe porosity structure: selfconsistent theories, for which each crack is treated as if it were embedded in a cracked background medium (following rock physics orthodoxy we use "crack" to identify any pore space), and noninteraction theories, which treat each crack as if it were isolated in an uncracked background. Strictly speaking, these theories are valid only for very small crack densities (i.e., for small porosities). As crack density is increased, self-consistent theories will tend to overestimate the softening effects of cracks; thus, for a given porosity, the velocity they predict will be too small. Conversely, noninteraction theories underestimate the effects of cracks, thereby predicting velocities that are too high for a given porosity. The disagreement between the theories at large porosities can be significantly reduced by treating the total porosity as if it has been built up recursively, a small number of cracks at a time, with each new crack "feeling" the cracks that came before but being unaffected by the cracks that have yet to be added. The result is a hybrid or an extended theory, which combines both noninteraction and self-consistent philosophies, and which is correct at least to the second order in the crack density (Berge et al., 1992; Cheng, 1978).

In order to infer pore shape distributions of oceanic crust from seismic data, extended versions of both the Kuster-Toksöz theory (Kuster and Toksöz, 1974a; 1974b) and the Walsh theory (Walsh, 1969) have previously been applied with success (Berge et al., 1992; Ludwig et al., in press). The resulting models provide a distribution of pore space volume over different pore shapes defined by their aspect ratio.

\section{Methodology}

To reproduce the compressional-wave and shear-wave velocities of the TAG samples measured at a confining pressure of $1 \mathrm{MPa}$, we applied an iterative modeling scheme using the extended Kuster-

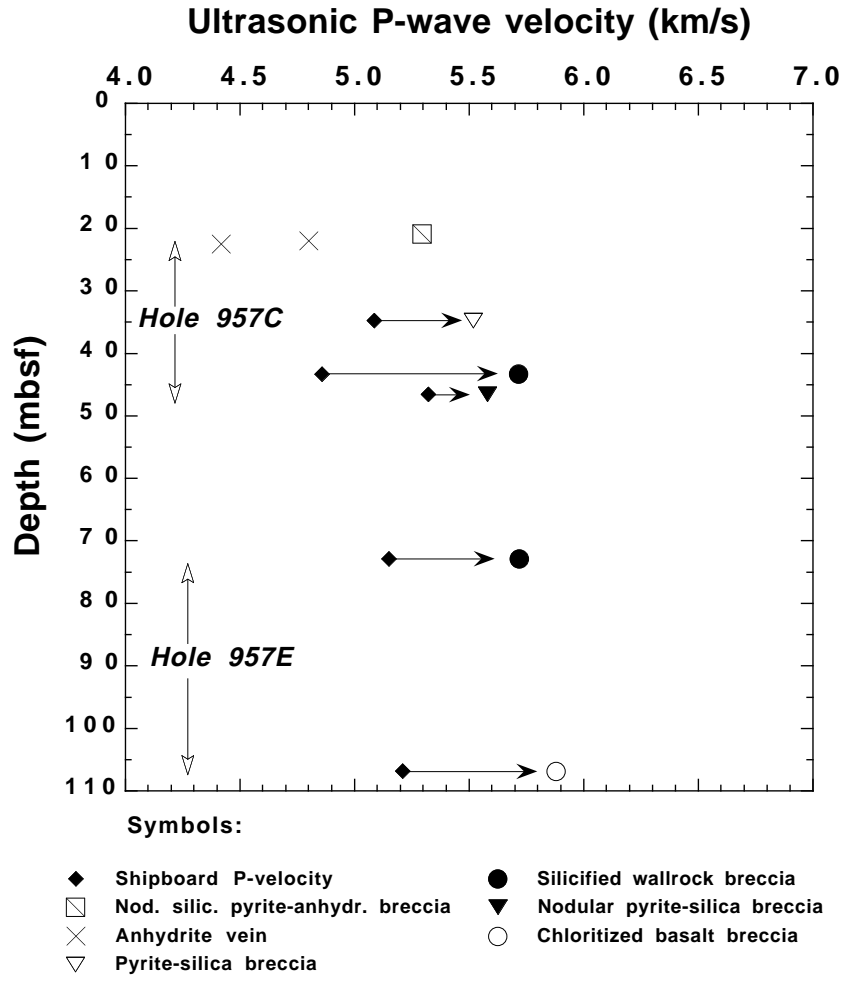

Figure 4. Results from ultrasonic compressional-wave velocity measurements at the TAG-1 area (east side of the Black Smoker Complex) and comparison with shipboard measurements using the "Hamilton Frame." (The vertical, open arrows indicate the depth range for samples from Holes 957C and 957E. The horizontal, filled arrows indicate the velocity change between the shipboard and the ultrasonic measurements).

Toksöz (KT+) theory, described by Berge (1991) and Berge et al. (1992), to several samples representing the major internal structure zones of the active TAG mound. Microscopic observations on minicore thin sections, together with index properties measurements, provided constraints on starting models for this nonunique parameter estimation problem. From these observations, we constructed models for seven aspect ratio $(\alpha)$ bins, ranging from vesicles $(\alpha=1)$ to thin elongated cracks $(\alpha=0.001)$. Elastic moduli and densities for both the background material and the pore fluid were also required as input parameters. Background material parameters were estimated from the mineralogy of the sample and the measured grain density (Tables 1,2). We assumed that pore fluid properties were similar to those of seawater, with a salinity of $3.5 \%$, a typical value for North Atlantic deep water (Sverdrup et al., 1942). The same salinity value was obtained for several bottom water measurements during Leg 158 (Humphris, Herzig, Miller, et al., 1996).

We used an iterative forward-modeling approach to construct a final porosity distribution model that best fits the ultrasonically measured velocities of a particular sample. During the first step, we computed the theoretical velocities corresponding to our starting porosity distribution model; our best guess constrained by microscopic observations and index properties measurements. We then compared the result with measured velocities listed in Table 3 and made small corrections to the previous model by changing the contribution to porosity in each bin. To make these corrective changes, we were guided by the known physical dependence of pore shape distribution and seismic velocities. The mathematical description of this relationship is beyond the scope of this paper, but it can be found in (Kuster and 


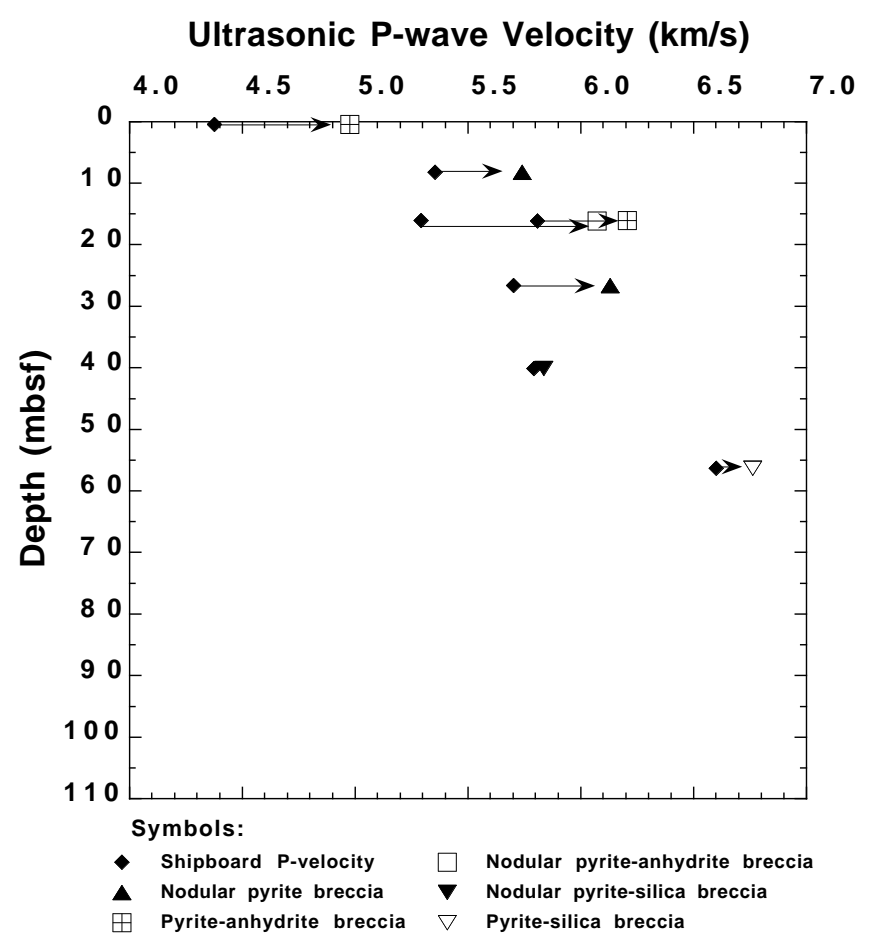

Figure 5. Results from ultrasonic compressional-wave velocity measurements at the TAG-5 area (north side of the Black Smoker Complex) and comparison with shipboard measurements using the "Hamilton Frame." (The horizontal arrows indicate the velocity change between the shipboard and the ultrasonic measurements.)
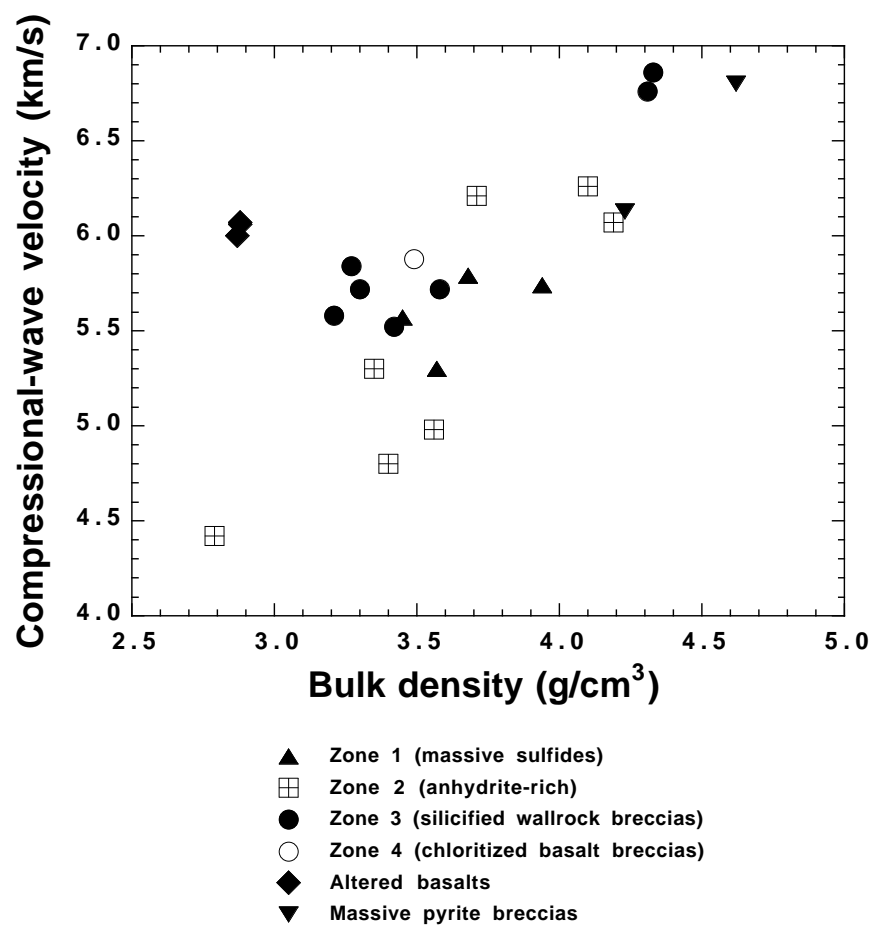

Figure 6. Compressional-wave velocity at $100 \mathrm{MPa}$ as a function of bulk density. The plot symbols correspond to the major internal structural zones of the active TAG mound.
Toksöz, 1974a). These equations describe how both $V_{p}$ and $V_{s}$ are affected as porosity at any particular aspect ratio is adjusted. In general, an increasing population of thin, water-filled cracks $(\alpha<0.01)$ will reduce $V_{s}$ faster than it reduces $V_{p}$, whereas an increasing population of thick, water-filled cracks $(\alpha>0.01)$ will reduce $V_{p}$ faster than $V_{s}$ (Shearer, 1988). Seismic velocities are less affected by high concentrations of large $\alpha$ pores than by high concentrations of small $\alpha$ pores. From this relationship, it is relatively straightforward to correct the porosity at each aspect ratio in order to achieve the desired velocities. These iterations were repeated until the theoretically computed velocities matched the measured ultrasonic velocities within $1 \%$, corresponding to the approximate resolution of the experiment. Clearly, this modeling approach does not yield a unique solution. However, the constraints on the starting model and the iteratively obtained improvements of the succeeding models, achieved through small alterations, assure that the final model reflects a reasonable estimate of the true pore shape distribution.

\section{Results and Observations}

The final porosity models for representative samples of each zone are shown in Figure 16. Porosity is plotted on a logarithmic scale vs. bins of aspect ratio. By summing the porosities in each aspect ratio bin, we obtain the total porosity.

A massive pyrite breccia, Sample 957F-1N-1, 62-64 cm, was chosen as a representative massive sulfide sample of Zone 1 . It has a very high concentration of sulfides ( $85 \%$ pyrite and $5 \%$ chalcopyrite; Table 2) and a grain density of $3.83 \mathrm{~g} / \mathrm{cm}^{3}$. Unfortunately, pore-shape constraints are very limited for this particular sample because the matching thin section was damaged during preparation. To match the observed compressional-wave and shear-wave velocities of $5.3 \mathrm{~km} / \mathrm{s}$ and $2.9 \mathrm{~km} / \mathrm{s}$, respectively, a relatively high concentration $(5.9 \%)$ of spherical pores $(\alpha=0.5-1.0)$ is required during modeling (Fig. 16). Pore spaces of smaller aspect ratio have lower concentrations, with the thin cracks of $\alpha=0.001$ having the lowest concentration $(0.5 \%)$. The total porosity for this sample after modeling is $9.9 \%$, compared with $9.3 \%$ obtained by the calculation of index properties.

The anhydrite-rich Zone 2 comprises two distinctive types of rocks: up to $45 \mathrm{~cm}$ long, almost pure anhydrite veins and sulfideanhydrite breccias. Sample 957C-7N-3, 15-17 cm, represents the first type, composed of $95 \%$ anhydrite and only $5 \%$ sulfide (Table 2). Microscopic analysis suggests a high total porosity, which is confirmed by index properties measurements that yielded a total porosity of $9.6 \%$. The modeled porosity distribution is presented in Figure 16. A high concentration of spherical pore spaces $(9.7 \%)$ is necessary to account for the high total porosity without considerable reduction in seismic velocities. The KT+ method yields a total porosity $(\Phi=$ $10.6 \%)$.

Sample 957P-1R-1, 49-51 cm, represents the second type of Zone 2 rocks, a pyrite-anhydrite breccia. Although this sample has a massive sulfide concentration of $70 \%$ and "only" $30 \%$ anhydrite, the measured seismic velocities $\left(V_{p}=4.98 \mathrm{~km} / \mathrm{s} ; V_{s}=2.78 \mathrm{~km} / \mathrm{s}\right)$ are only slightly higher than those for the almost pure anhydrite sample $\left(V_{p}=\right.$ $4.42 \mathrm{~km} / \mathrm{s} ; V_{s}=2.53 \mathrm{~km} / \mathrm{s}$ ). This can be explained by the high total porosity of the pyrite-anhydrite sample, calculated at almost $16 \%$ from index properties measurements. The sample's modeled porosity distribution is presented in Figure 16. The concentration of $\alpha=0.5-$ 1.0 pore spaces is high at $11.8 \%$ (as in the anhydrite vein sample). In addition, modeling pore space distribution for Sample 957P-1R-1, $49-51 \mathrm{~cm}$, requires a high concentration of "crack-like" pore spaces ( $\alpha=0.001-0.05$ ) of $5.0 \%$ to $5.6 \%$. After modeling, the total porosity value of $17.2 \%$ is very high. However, the modeling results agree well with microscopic observations showing elongated cracks and unfilled voids near the intrusion of anhydrite veins (Table 2).

Sample 957C-16N-1, 35-37 cm, a nodular pyrite-silica breccia, is representative of Zone 3, the increasingly silicified part of the TAG 

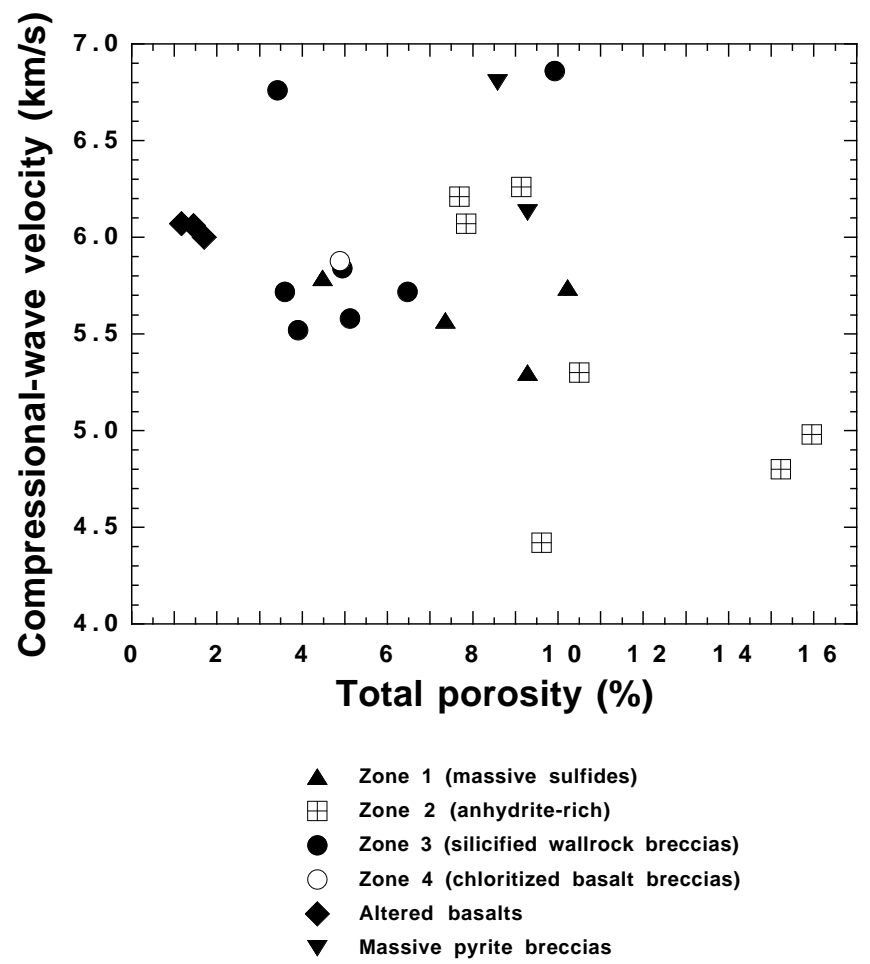

Figure 7. Compressional-wave velocity at $100 \mathrm{MPa}$ as a function of total porosity. The plot symbols correspond to the major internal structural zones of the active TAG mound.

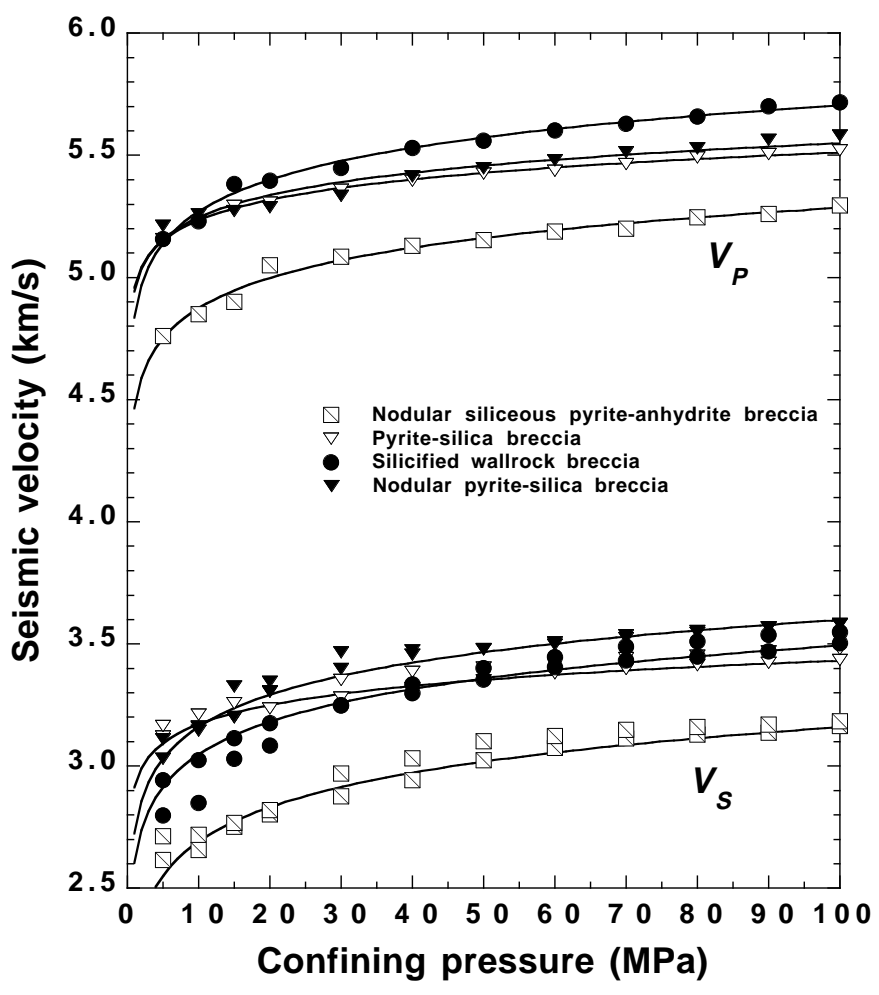

Figure 8. Compressional-wave $\left(V_{p}\right)$ and shear-wave $\left(V_{s}\right)$ velocities as functions of confining pressure for sulfide samples from the TAG-1 area (southeast side of the Black Smoker Complex). In order to better distinguish the velocity-pressure curves, lines are plotted for each sample, representing a logarithmic fit to the data. mound. Thin-section analyses indicate an intermediate porosity, with many pyrite nodules surrounded by cavities and cracks. Pore space modeling results for this sample are shown in Figure 16. Ultrasonic velocity measurements $\left(V_{p}=5.58 \mathrm{~km} / \mathrm{s} ; V_{s}=3.58 \mathrm{~km} / \mathrm{s}\right)$ were matched by a relatively high concentration of "sphere-like" pores and a low concentration of small aspect ratio pore spaces. This is in agreement with a low $V_{p} / V_{s}$ ratio, shown in Figure 11 . The total porosity calculated with the $\mathrm{KT}+$ method is $5.5 \%$, whereas the value obtained from index properties measurements is $5.1 \%$.

One chloritized basalt breccia from Zone 4, Sample 957E-15R-1, 30-32 cm, was analyzed. Its aspect ratio distribution, shown in Figure 16, suggests a broad spectrum of pore spaces with mostly vesicular pores and few extremely thin cracks. Total porosity values are $5.8 \%$ and $4.9 \%$ from $\mathrm{KT}+$ and index properties calculations, respectively.

The last minicore analyzed for porosity distribution was a basalt sample recovered at TAG-4 (west of the Black Smoker Complex) at a depth of about 47 mbsf. Because all basalt samples showed very similar characteristics during physical properties measurements, Sample 957M-10R-1, 39-41 cm, is taken as representative of the basalt samples recovered from Hole 957M (Tables 1-3). Index properties measurements show a very low total porosity of $1.7 \%$, and the modeled porosity distribution for this sample is shown in Figure 16. Although there is a broad peak corresponding to vesicular pore spaces $(\alpha=0.5-1.0)$, small aspect ratio pore spaces (i.e., thin cracks) contribute very little to the total porosity of the basalt sample. This agrees well with microscopic observations of mostly vesicular pore spaces. However, to match the ultrasonic velocity measurements, a slightly higher than expected total porosity is required by the KT+ theory $(\Phi$ $=1.9 \%$ ). Elastic moduli of "normal" oceanic crust basalt, which were used as input parameters for the modeling, are probably "stiffer" than

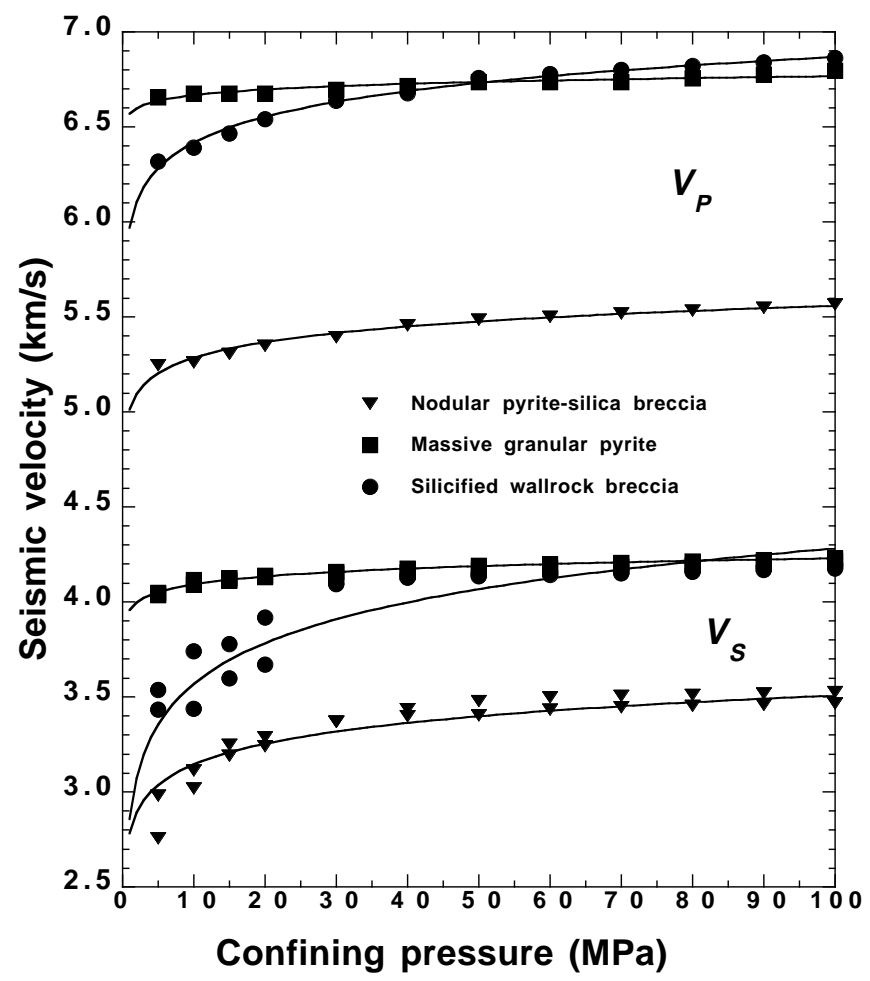

Figure 9. Compressional-wave $\left(V_{p}\right)$ and shear-wave $\left(V_{s}\right)$ velocities as functions of confining pressure for sulfide samples from the TAG-2 area (Kremlin White Smoker Complex). In order to better distinguish the velocity-pressure curves, lines are plotted for each sample, representing a logarithmic fit to the data. 


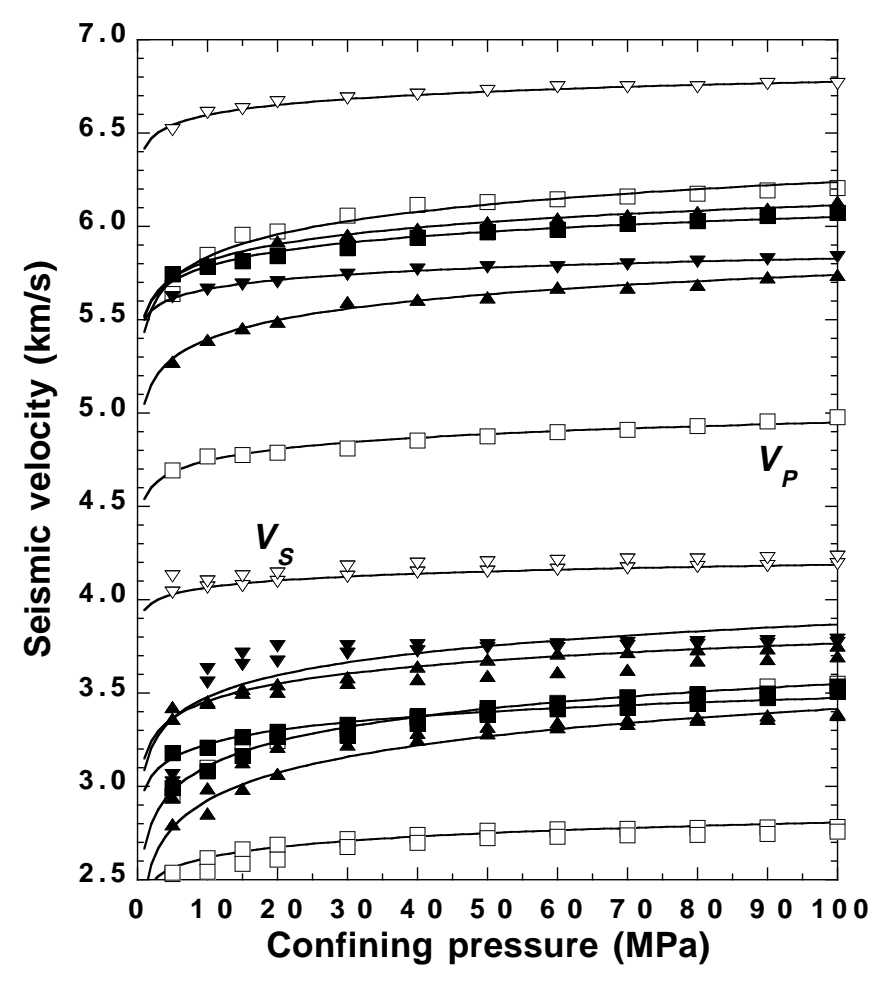

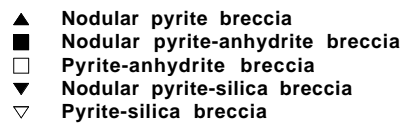

Figure 10. Compressional-wave $\left(V_{p}\right)$ and shear-wave $\left(V_{s}\right)$ velocities as functions of confining pressure for sulfide samples from the TAG-5 area (north side of the Black Smoker Complex). In order to better distinguish the velocity-pressure curves, lines are plotted for each sample, representing a logarithmic fit to the data.

the actual elastic moduli of the background material of the TAG basalts because of softening effects of altered vs. unaltered grains. However, even if the correct moduli were known, we would expect the overall porosity distribution to remain similar.

\section{Discussion}

The extended Kuster-Toksöz theory was applied for the first time on a hand-sample scale. In summary, modeling of pore-shape distribution in relation to ultrasonic measurements on minicores, which represent the different lithologies drilled in the TAG mound, yields satisfactory results. The reliability of models is greatly improved wherever microscopic pore-shape observations are available.

The total porosity values obtained from the models are consistently higher than those obtained from direct index properties calculations. The explanation for this is two-fold. First, the elastic moduli used as model input parameters may be too "stiff," thereby requiring porosities that are too high in order to match the seismic data. Second, index properties measurements probably underestimate the total porosity because of the assumptions that all pore spaces are interconnected, a very unlikely scenario for the multimineral structures of most of the TAG samples, and fluid-saturation during wet-sample experiments. Estimating an error margin for the assumed elastic moduli of the background material is very difficult because of the heterogeneity of the brecciated samples. Therefore, the results of this modeling are somewhat speculative. However, without other available porosity structure
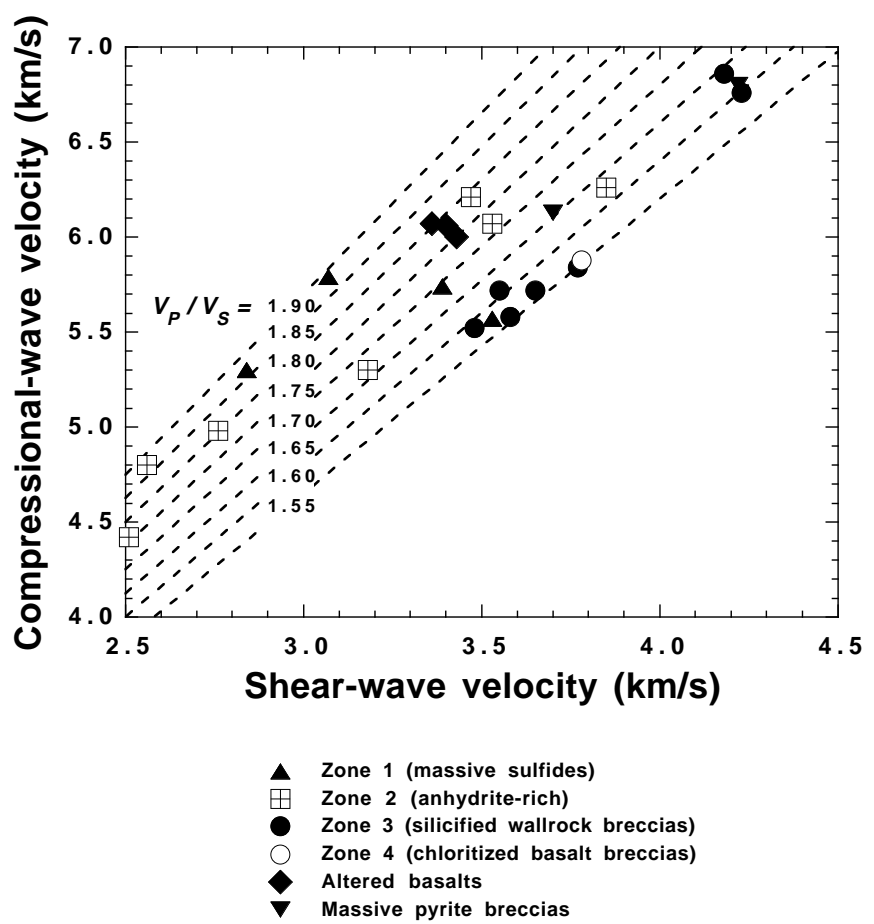

Figure 11. Compressional-wave velocity $\left(V_{p}\right)$ over shear-wave velocity $\left(V_{s}\right)$ ratio for all minicore samples measured at $100 \mathrm{MPa}$. Lines of constant $V_{p} / V_{s}$ are shown.

information, these porosity models provide a first-order estimate that matches both the limited visual observations of pore shapes and the seismic velocity measurements.

\section{SUMMARY AND CONCLUSIONS}

Results from this study provide a unique reference set for the physical properties of sulfide, sulfate, and basalt samples from an active sediment-free hydrothermal system. In general, seismic velocities, densities, porosities, and pore space distribution are extremely variable within very short horizontal and vertical distances of the hydrothermally active mound.

Ultrasonic measurements on 24 minicores yield a substantial data set of both compressional-wave and shear-wave velocities at elevated pressures, that are more indicative of in situ conditions than the shipboard seismic measurements of only $P$-waves at atmospheric pressures. A general increase in $V_{p}$ with depth is observed for all samples and is probably caused by increased cementation and silicification of the mostly brecciated rocks. The different rock types have distinct $V_{p} / V_{s}$ ratios, illustrating the importance of measuring both $V_{p}$ and $V_{s}$. Massive sulfide samples of Zone 1 show a preferential direction for $S$-wave propagation, which may be related to their location within the mound. Anhydrite-rich rocks of Zone 2 exhibit a clear trend of increasing $V_{p}$ with increasing densities and decreasing porosities. Rocks of Zones 2 and 3 show a seismic velocity dependence on total sulfide mineral concentration. Porosity effects on seismic velocities increase with higher anhydrite concentration of the rocks. An almost pure anhydrite sample exhibited velocity hysteresis in response to decreasing confining pressure. Basalt velocities deviate from "normal" mid-ocean ridge basalt velocities because of hydrothermal alteration, rather than porosity effects.

Porosity distribution models were calculated for representative samples of each major lithologic zone within the TAG mound. Mi- 


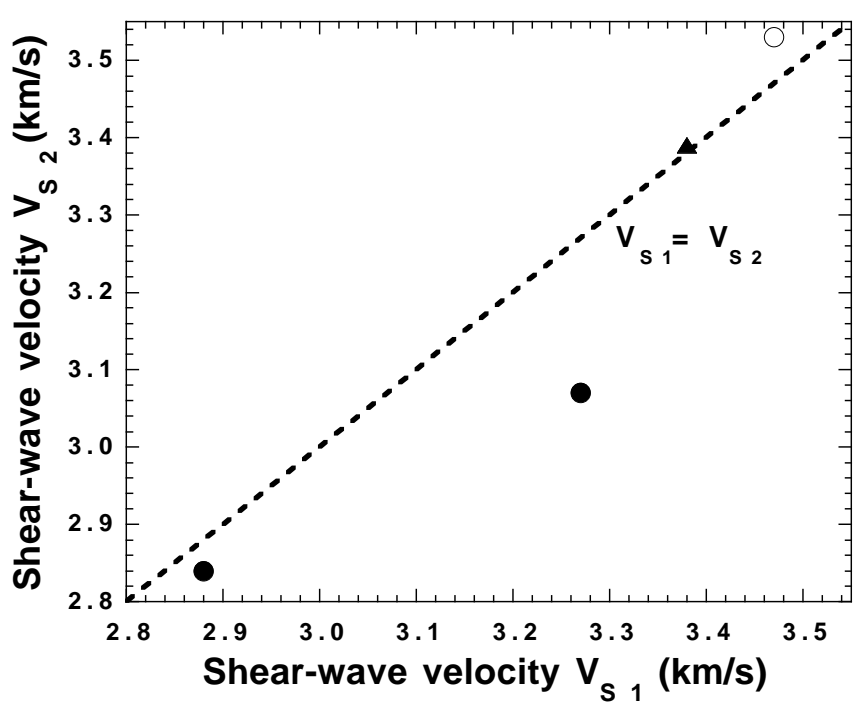

- TAG-1 (massive sulfides)

TAG-2 (massive sulfides)

- TAG-5 (massive sulfides)

Figure 12. A plot of the relationship between the velocities of the two orthogonal shear waves ( $S 1$ and $S 2$ ) for massive sulfides of the upper Zone 1 at a confining pressure of $100 \mathrm{MPa}$. A distinct shear-wave velocity anisotropy was measured on samples from the TAG-1 Area (southeast side of the Black Smoker Complex).

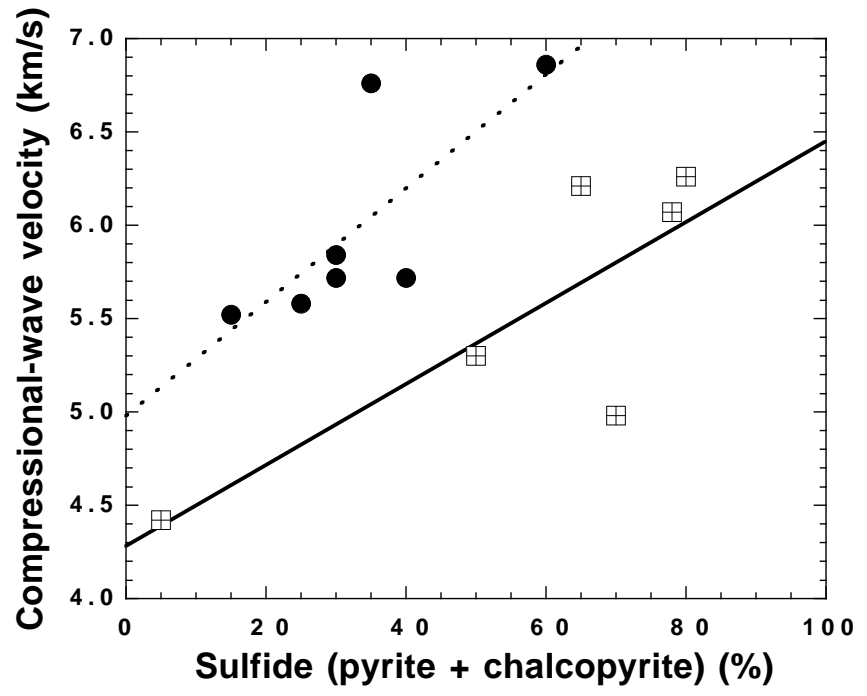

- Z-Zone 2 (anhydrite-rich)

- - Zone 3 (silicified wallrock breccias)

Figure 13. Compressional-wave velocity measured at $100 \mathrm{MPa}$ as a function of the concentration of major sulfide minerals in the samples. Minicores from the anhydrite-rich Zone 2 and minicores from the intensely silicified wallrock breccia Zone 3 show a positive correlation. A least-squares fit has been applied to the data to show the trend. The correlation coefficient is 0.804 for samples from Zone 2 and 0.759 for samples from Zone 3 .

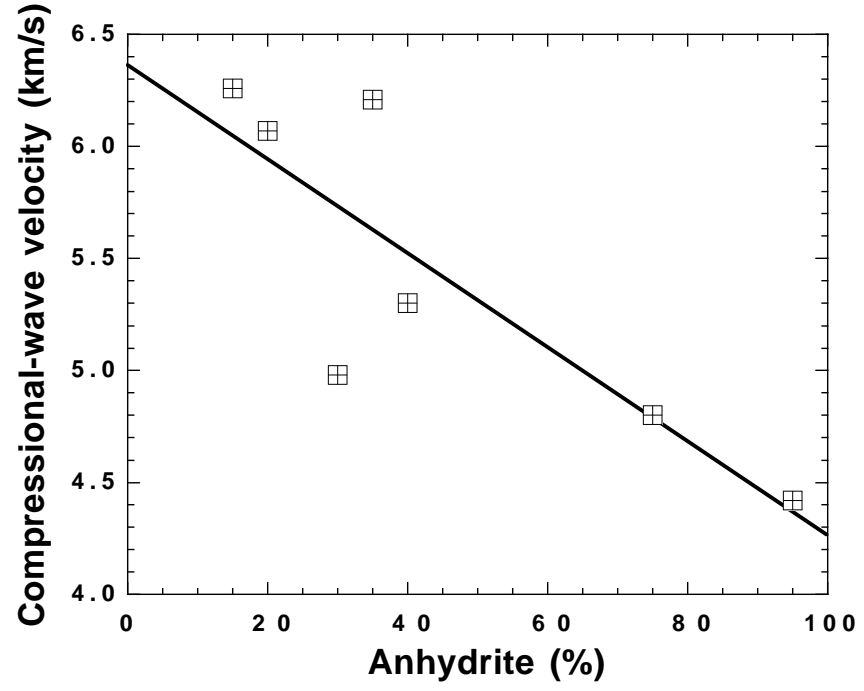

- Zone 2 (anhydrite-rich)

Figure 14. Compressional-wave velocity measured at $100 \mathrm{MPa}$ as a function of the anhydrite concentration in the samples. Minicores from the anhydriterich Zone 2 show a negative correlation. A least-squares fit has been applied to the data to show the trend. The correlation coefficient is 0.834 .

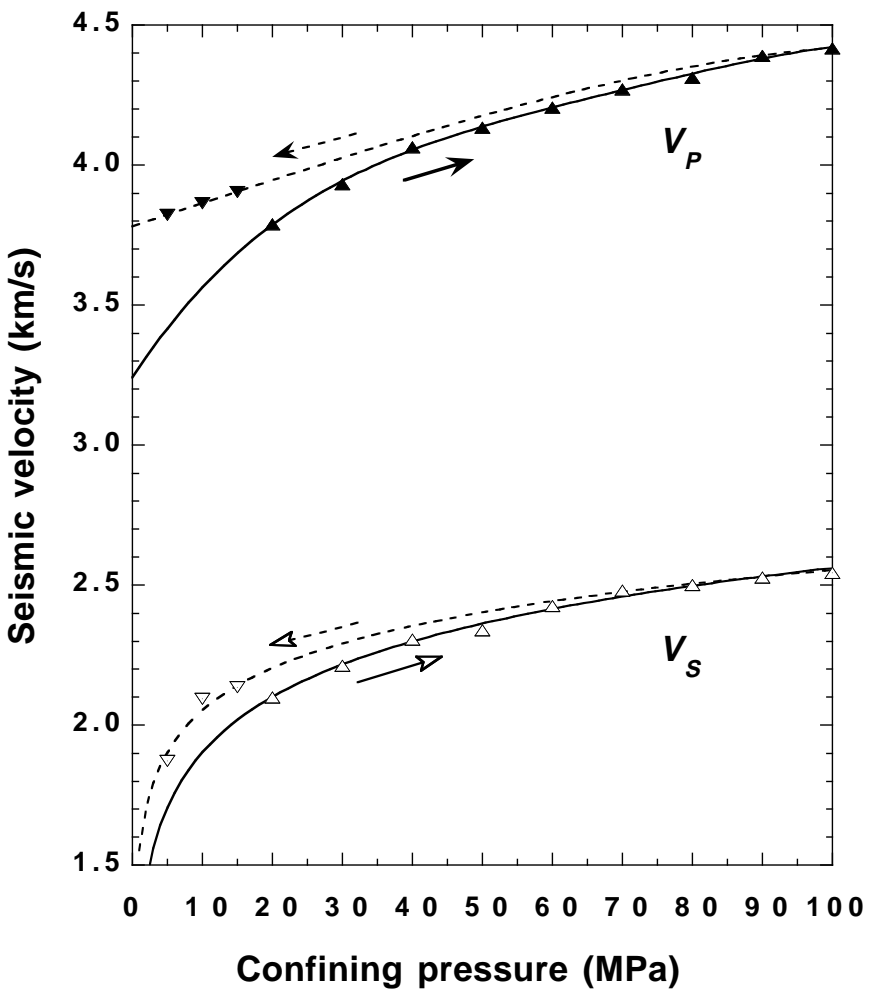

Figure 15. Compressional-wave $\left(V_{p}\right)$ and shear-wave $\left(V_{s}\right)$ velocities as functions of confining pressure for anhydrite Sample $158-957 \mathrm{C}-7 \mathrm{~N}-3,15-17 \mathrm{~cm}$. Both compressional-wave and shear-wave velocities show hysteresis between measurements at increasing pressures (upward-pointing triangles and solid lines) and measurements at decreasing pressures (downward-pointing triangles and broken lines) as a result of only partial reopening of cracks. The arrows indicate the sequence of measurements. 
Figure 16. Final aspect ratio distribution models of pore shapes for representative samples of all major lithologic zones of the TAG mound after using the extended Kuster-Toksöz (KT+) theory. Porosity is plotted on a logarithmic scale vs. bins of aspect ratio. The sum of all porosity values in each aspect ratio bin is the total porosity of the sample.

croscopic analyses provide constraints on the models and improve their reliability. Total porosity obtained by modeling is consistently higher than the values obtained from index properties measurements. The discrepancies can be explained by the errors in the assumptions for both methods.

Our results show that the theories of porosity distribution in terms of aspect ratios can be transferred to rock samples at a hand-sample scale. Modeling provides a tool with which the links between porosity, permeability, fluid flow, geochemical fluxes, and alteration mechanisms can be explored. At present, the inversion procedure to obtain aspect ratio distribution from laboratory velocity measurements is done by trial and error in an ad hoc manner. A goal for future work is to automate this step and to obtain more objective results.

\section{ACKNOWLEDGMENTS}

RJL thanks JOI-USSAC for post-cruise funding of this study, Gerard J. Fryer for thoughtful remarks on the manuscript, Gregor Eberli for allowing the use of his laboratory, Flavio Anselmetti for stimulating conversations late at night, Masataka Kinoshita, and an anonymous reviewer for very constructive comments.

\section{REFERENCES}

Berge, P.A., 1991. Seismic anisotropy and velocity-porosity relationships in the seafloor [Ph.D. dissert.], Univ. of Hawaii, Honolulu.

Berge, P.A., Fryer, G.J., and Wilkens, R.H., 1992. Velocity-porosity relationships in the upper oceanic crust: theoretical considerations. J. Geophys. Res., 97:15239-15254

Cheng, C.H., 1978. Seismic velocities in porous rocks: direct and inverse problems [Ph.D. dissert.]. Mass. Inst. Tech., Cambridge, MA.

Christensen, N.I., and Salisbury, M.H., 1975. Structure and constitution of the lower oceanic crust. Rev. Geophys. Space Phys., 13:57-86.

Clark, S.P. (Ed.), 1966. Handbook of Physical Constants. Mem. Geol. Soc. Am., 97.

Gröschel-Becker, H.M., Villinger, H.W., Konyukhov, B.A., Iturrino, G.J., and Christensen, N.I., 1994. Seismic velocities of diabase and basalt from Middle Valley sills and flows, northern Juan de Fuca Ridge. In Mottl, M.J., Davis, E.E., Fisher, A.T., and Slack, J.F. (Eds.), Proc. ODP, Sci. Results, 139: College Station, TX (Ocean Drilling Program), 597612.

Hannington, M.D., Jonasson, I.R., Herzig, P.M., and Petersen, S., 1995. Physical, chemical processes of seafloor mineralization at mid-ocean ridges. In Humphris, S.E., et al. (Eds.), Seafloor Hydrothermal Systems: Physical, Chemical, Biological and Geological Interactions. Am. Geophys. Union Monogr., 91:115-157.

Humphris, S.E., Herzig, P.M., Miller, D.J., Alt, J.C., Becker, K., Brown, D., Brügmann, G., Chiba, H., Fouquet, Y., Gemmell, J.B., Guerin, G., Hannington, M.D., Holm, N.G., Honnorez, J.J., Itturino, G.J., Knott, R., Ludwig, R., Nakamura, K., Petersen, S., Reysenbach, A.-L., Rona, P.A., Smith, S., Sturz, A.A., Tivey, M.K., and Zhao, X., 1995. The internal structure of an active sea-floor massive sulphide deposit. Nature, 377:713-716.

Humphris, S.E., Herzig, P.M., Miller, D.J., et al., 1996. Proc. ODP, Init. Repts., 158: College Station, TX (Ocean Drilling Program).

Iturrino, G.J., Christensen, N.I., Becker, K., Boldreel, L.O., Harvey, P.K.H., and Pezard, P., 1995. Physical properties and elastic constants of upper crustal rocks from core-log measurements in Hole 504B. In Erzinger, J., Becker, K., Dick, H.J.B., and Stokking, L.B. (Eds.), Proc. ODP, Sci. Results, 137/140: College Station, TX (Ocean Drilling Program), 273292.

Iturrino, G.J., Christensen, N.I., Kirby, S., and Salisbury, M.H., 1991. Seismic velocities and elastic properties of oceanic gabbroic rocks from Hole 735B. In Von Herzen, R.P., Robinson, P.T., et al., Proc. ODP, Sci. Results, 118: College Station, TX (Ocean Drilling Program), 227-244.

Johnston, J.E., Fryer, G.J., and Christensen, N.I., 1995. Velocity-porosity relationships of basalts from the East Pacific Rise. In Batiza, R., Storms, M.A., and Allan, J.F. (Eds.), Proc. ODP, Sci. Results, 142: College Station, TX (Ocean Drilling Program), 51-59.

Kuster, G.T., and Toksöz, M.N., 1974a. Velocity and attenuation of seismic waves in two-phase media, Part I: theoretical formulations. Geophysics, 39:587-606.

, 1974b. Velocity and attenuation of seismic waves in two-phase media, Part II: experimental results. Geophysics, 39:607-618.

Ludwig, R.J., Fryer, G.J., Christeson, G.L., and Purdy, G.M., in press. Porosity and evolution of the shallow oceanic crust at the East Pacific Rise. $J$. Geophys. Res.

McGregor, B.A., Harrison, C.G.A., Lavelle, J.W., and Rona, P.A., 1977. Magnetic anomaly patterns on Mid-Atlantic Ridge crest at $26^{\circ} \mathrm{N}$. J. Geophys. Res., 82:231-238.

Rona, P.A., Bogdanov, Y.A., Gurvich, E.G., Rimski-Korsakov, A., Sagalevitch, A.M., Hannington, M.D., and Thompson, G., 1993. Relict hydrothermal zones in the TAG hydrothermal field, Mid-Atlantic Ridge $26^{\circ} \mathrm{N}$, 45W. J. Geophys. Res., 98:9715-9730.

Rona, P.A., Klinkhammer, G., Nelson, T.A., Trefry, J.H., and Elderfield, H., 1986. Black smokers, massive sulfides and vent biota on the Mid-Atlantic Ridge. Nature, 321:33-37.

Shearer, P., and Orcutt, J., 1985. Anisotropy in the oceanic lithospheretheory and observations from the Ngendei seismic refraction experiment in the south-west Pacific. Geophys. J. R. Astron. Soc., 80:493-526. 
Shearer, P.M., 1988. Cracked media, Poisson's ratio and the structure of the oceanic crust. J. Geophys. Res., 92:357-362.

Sverdrup, H.U., Johnson, M.W., and Fleming, R. (Eds.), 1942. The Oceans: Their Physics, Chemistry and General Biology: Englewood Cliffs, NJ (Prentice-Hall)

Walsh, J.B., 1969. New analysis of attenuation in partially melted rock. $J$. Geophys. Res., 74:4333-4337.

Wilkens, R.H., Fryer, G.J., and Karsten, J., 1991. Evolution of porosity and seismic structure of upper oceanic crust: importance of aspect ratios. $J$. Geophys. Res., 96:17,891-17,995.
Date of initial receipt: 3 June 1996

Date of acceptance: 4 April 1997

Ms 158SR-225

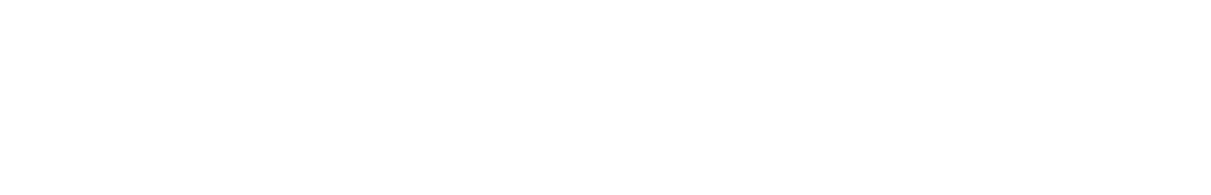

